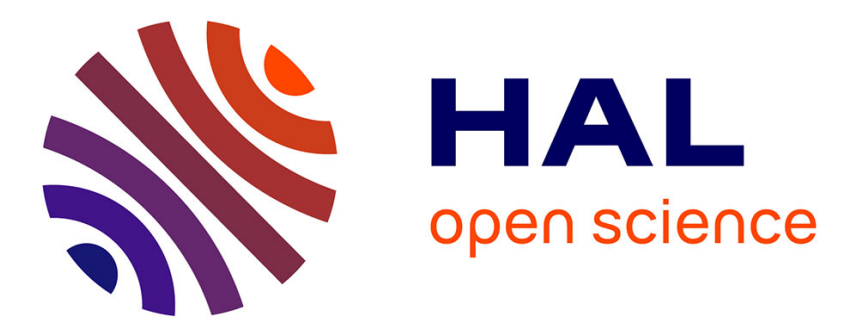

\title{
Twenty-one years of passive sampling monitoring of SO2 , NO2 and O3 at the Cape Point GAW station, South Africa
}

J.-S Swartz, P G van Zyl, J P Beukes, C Labuschagne, E.-G Brunke, Thierry Portafaix, Corinne Galy-Lacaux, J J Pienaar

\section{To cite this version:}

J.-S Swartz, P G van Zyl, J P Beukes, C Labuschagne, E.-G Brunke, et al.. Twenty-one years of passive sampling monitoring of SO2, NO2 and $\mathrm{O} 3$ at the Cape Point GAW station, South Africa. Atmospheric Environment, In press, 10.1016/j.atmosenv.2019.117128 . hal-02385761

\section{HAL Id: hal-02385761 https://hal.science/hal-02385761}

Submitted on 29 Nov 2019

HAL is a multi-disciplinary open access archive for the deposit and dissemination of scientific research documents, whether they are published or not. The documents may come from teaching and research institutions in France or abroad, or from public or private research centers.
L'archive ouverte pluridisciplinaire HAL, est destinée au dépôt et à la diffusion de documents scientifiques de niveau recherche, publiés ou non, émanant des établissements d'enseignement et de recherche français ou étrangers, des laboratoires publics ou privés. 
archives-ouvertes

\title{
Atmospheric Environment xxx (xxxx) xxx Twenty-one years of passive sampling monitoring of SO $2, \mathrm{NO} 2$ and O 3 at the Cape Point GAW station, South Africa
}

\author{
J.-S Swartz, P van Zyl, J Beukes, C Labuschagne, E.-G Brunke, Thierry
}

Portafaix, C Galy-Lacaux, J Pienaar

\section{To cite this version:}

J.-S Swartz, P van Zyl, J Beukes, C Labuschagne, E.-G Brunke, et al.. Atmospheric Environment $\mathrm{xxx}(\mathrm{xxxx}) \operatorname{xxx}$ Twenty-one years of passive sampling monitoring of SO 2 , NO 2 and O 3 at the Cape Point GAW station, South Africa. Atmospheric Environment, Elsevier, 2019, 10.1016/j.atmosenv.2019.117128 . hal-02385761

\section{HAL Id: hal-02385761 \\ https://hal.archives-ouvertes.fr/hal-02385761}

Submitted on 29 Nov 2019

HAL is a multi-disciplinary open access archive for the deposit and dissemination of scientific research documents, whether they are published or not. The documents may come from teaching and research institutions in France or abroad, or from public or private research centers.
L'archive ouverte pluridisciplinaire $\mathbf{H A L}$, est destinée au dépôt et à la diffusion de documents scientifiques de niveau recherche, publiés ou non, émanant des établissements d'enseignement et de recherche français ou étrangers, des laboratoires publics ou privés. 


\title{
Twenty-one years of passive sampling monitoring of $\mathrm{SO}_{2}, \mathrm{NO}_{2}$ and $\mathrm{O}_{3}$ at the Cape Point GAW station, South Africa
}

\author{
J.-S. Swartz ${ }^{\text {a }}$, P.G. Van Zyl ${ }^{\text {a, }}$, J.P. Beukes ${ }^{\text {a }}$, C. Labuschagne ${ }^{\text {b }}$, E.-G. Brunke ${ }^{\text {a }}$, T. Portafaix ${ }^{\text {, }}$, \\ C. Galy-Lacaux ${ }^{\text {d }}$, J.J. Pienaar ${ }^{a}$ \\ ${ }^{\text {a }}$ Unit for Environmental Sciences and Management, North-West University, Potchefstroom Campus, Potchefstroom, 2520, South Africa \\ ${ }^{\mathrm{b}}$ South African Weather Service c/o CSIR, P.O. Box 320, Stellenbosch, 7599, South Africa \\ ${ }^{\mathrm{c}}$ Laboratoire de l'Atmosphére et des Cyclones, UMR CNRS 8105, Universite de La Reunion, Reunion Island, France \\ ${ }^{\mathrm{d}}$ Laboratoire d'Aerologie, UMR 5560, Université Paul-Sabatier (UPS) and CNRS, Toulouse, France
}

\section{H I G H L I G H T S}

- Seasonal variability attributed to changes in meteorology and source contribution.

- $\mathrm{O}_{3}$ seasonal pattern corresponded to the $\mathrm{NO}_{2}$ seasonality.

- Global forcing factors contributed mainly to $\mathrm{SO}_{2}$ variability.

- Local and regional factors contributed mainly to $\mathrm{NO}_{2}$ and $\mathrm{O}_{3}$ fluctuations.

- $\mathrm{SO}_{2}, \mathrm{NO}_{2}$ and $\mathrm{O}_{3}$ concentrations remained relatively constant over 21 years.

\section{A R T I C L E I N F O}

\section{Keywords:}

Low-cost sensor

INDAAF

DEBITS

Inorganic gaseous species

Multiple linear regression

Long-term trend

\begin{abstract}
A B S T R A C T
Sulphur dioxide $\left(\mathrm{SO}_{2}\right)$, nitrogen dioxide $\left(\mathrm{NO}_{2}\right)$ and ozone $\left(\mathrm{O}_{3}\right)$ are considered typical inorganic gaseous pollutants in the atmosphere. The aim of this study was to assess long-term seasonal and inter-annual trends of a 21year $\mathrm{SO}_{2}, \mathrm{NO}_{2}$ and $\mathrm{O}_{3}$ passive sampling (monthly means) dataset collected at the Cape Point Global Atmosphere Watch (CPT GAW) station. Comparison of the concentrations of these gaseous species with other IGAC DEBITS Africa measurement sites indicated that levels of these species were generally similar to other African inland ecosystems, but lower compared to an industrial site in southern Africa. The $\mathrm{SO}_{2}, \mathrm{NO}_{2}$ and $\mathrm{O}_{3}$ monthly mean concentrations showed seasonal patterns, which can be attributed to various factors influencing levels of these species at CPT GAW. These factors are generally season specific, which include changes in meteorological conditions and source contributions. Higher $\mathrm{NO}_{2}$ concentrations were also attributed to increased microbial activity in the wet season. The $\mathrm{O}_{3}$ seasonal pattern corresponded to the $\mathrm{NO}_{2}$ seasonality, which was attributed to their related chemistry. $\mathrm{SO}_{2}$ and $\mathrm{NO}_{2}$ concentrations displayed inter-annual variability, while $\mathrm{O}_{3}$ did not indicate significant inter-annual fluctuations. The seasonal and inter-annual variability was explored with a multilinear regression model, in which global, regional and local meteorological factors, as well as population growth were included. Modelling results indicated that variances in $\mathrm{SO}_{2}$ concentrations were predominantly influenced by changes in global forcing factors. Global, regional and local factors played a significant role in $\mathrm{NO}_{2}$ trends, which included the influence of population growth and associated increased anthropogenic activities. It was also established that variances in $\mathrm{O}_{3}$ concentrations were predominantly associated with regional and local factors. Trend analysis indicated that $\mathrm{SO}_{2}, \mathrm{NO}_{2}$ and $\mathrm{O}_{3}$ concentrations remained relatively constant over the 21-year sampling period at this background site in the Southern Hemisphere.
\end{abstract}

\footnotetext{
* Corresponding author. Private Bag X6001, Potchefstroom, 2520, South Africa.

E-mail addresses: 20564759@nwu.ac.za (J.-S. Swartz), pieter.vanzyl@nwu.ac.za (P.G. Van Zyl), paul.beukes@nwu.ac.za (J.P. Beukes), Casper.Labuschagne@ weathersa.co.za (C. Labuschagne), egbrunke@gmail.com (E.-G. Brunke), thierry.portafaix@univ-reunion.fr (T. Portafaix), corinne.galy-lacaux@aero.obs-mip.fr (C. Galy-Lacaux), kobus.pienaar@nwu.ac.za (J.J. Pienaar).
} 


\section{Introduction}

In recent history, it has become apparent that the atmospheric chemical composition is being altered over a range of scales by means of increased anthropogenic activity (Monks and Leigh, 2009). It is, therefore, necessary to study the spatial and temporal evolution of the chemical composition of the atmosphere in order to evaluate the extent of anthropogenic and natural influences on the atmosphere. Atmospheric chemical species include inorganic trace gases emitted naturally and anthropogenically into the troposphere, which are subjected to various physical and chemical transformations (Seinfeld and Pandis, 2006). Atmospheric trace gases can be transported over long distances before being either deposited directly on to the earth's surface through dry deposition processes, or dissolved into airborne moisture and subsequently deposited during precipitation events.

Sulphur dioxide $\left(\mathrm{SO}_{2}\right)$, nitrogen dioxide $\left(\mathrm{NO}_{2}\right)$ and ozone $\left(\mathrm{O}_{3}\right)$ are considered to be typical pollutant atmospheric inorganic gaseous species. Atmospheric $\mathrm{SO}_{2}$ is usually associated with anthropogenic activities, which generally include the combustion of fossil fuels (Connell, 2005) and pyrometallurgical production processes (Venter et al., 2012; Van Zyl et al., 2014). Nitrogen oxide (NO) is emitted from natural, e.g. lightning and microbial, activity in soils, as well as anthropogenic sources, e.g. fossil fuel combustion, which is rapidly oxidised to $\mathrm{NO}_{2}$ (Connell, 2005). Tropospheric $\mathrm{O}_{3}$ is a secondary pollutant formed through the photochemical oxidation of $\mathrm{NO}_{2}$ in the presence of VOCs and CO (Laban et al., 2018). These species are mainly associated with

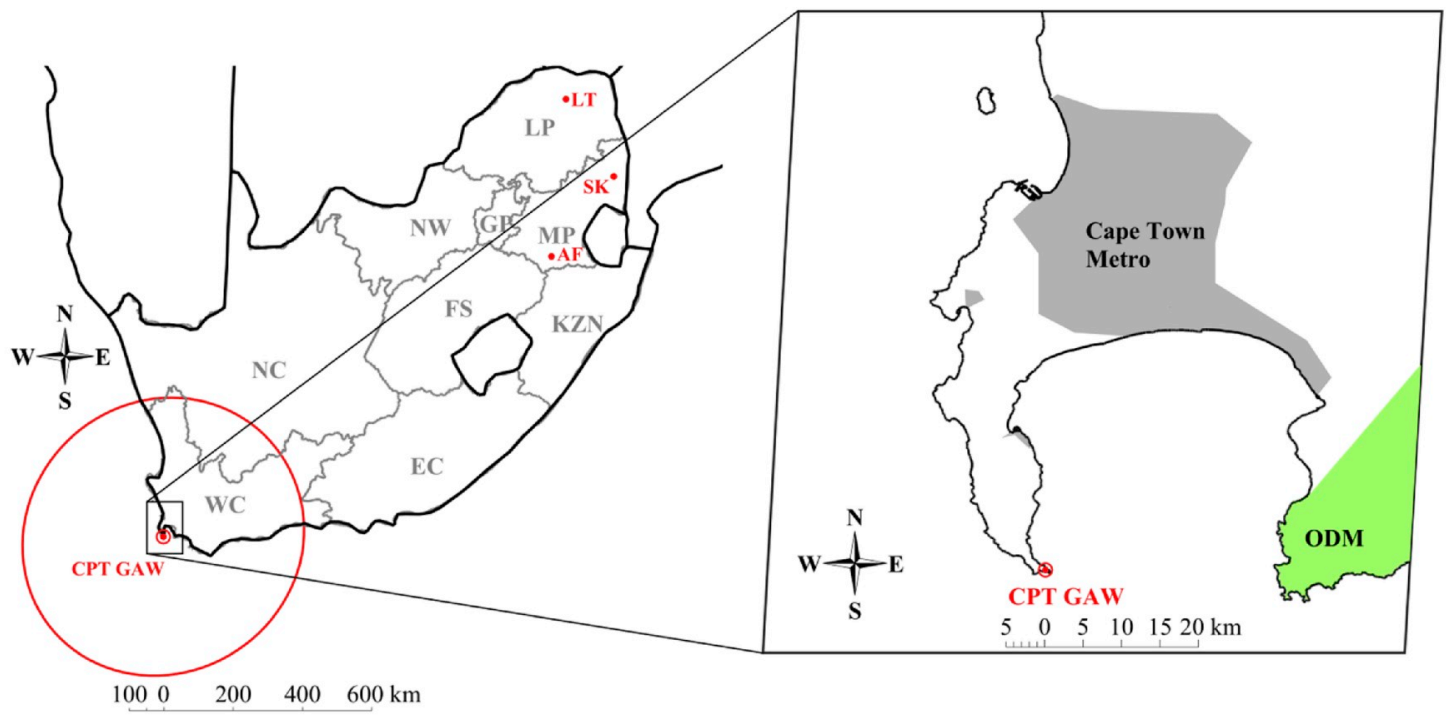

(a)

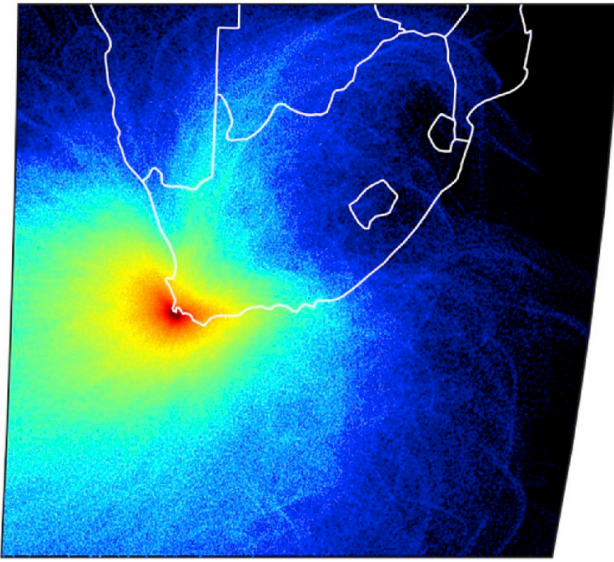

(b)
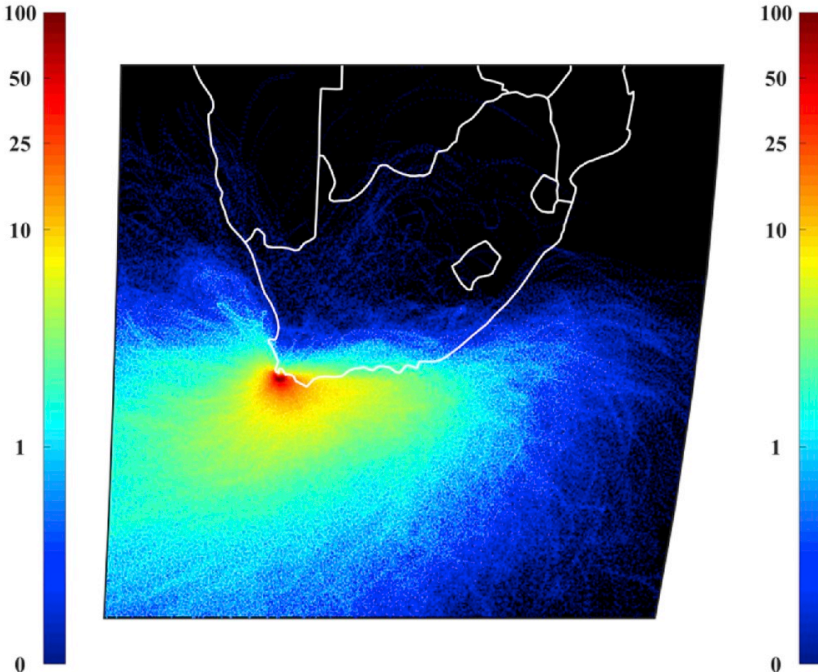

(c)

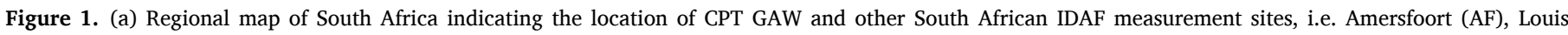

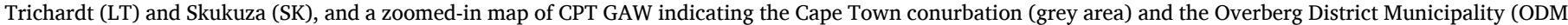

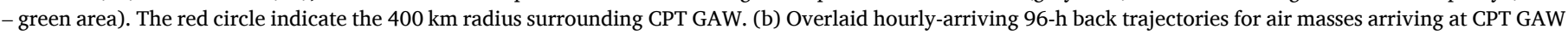

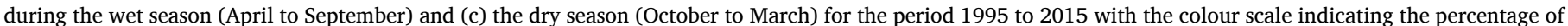
air masses passing over $0.2^{\circ} \times 0.2^{\circ}$ grid cells. 
general air quality, which includes detrimental influences on human health and disturbances of the natural equilibrium of ecosystems. Tropospheric $\mathrm{O}_{3}$ is also considered to be an important greenhouse gas. In addition to the influence of natural and anthropogenic sources on the atmospheric concentrations of $\mathrm{SO}_{2}, \mathrm{NO}_{2}$ and $\mathrm{O}_{3}$, local, regional and global meteorological patterns also influence the atmospheric concentrations of these species.

Comprehensive assessments on air quality (Monks and Leigh, 2009) and atmosphere-biosphere interactions (Fowler et al., 2009; Laban et al., 2018) indicated the importance of long-term atmospheric chemistry measurements. The Deposition of Biogeochemically Important Trace Species (DEBITS) task of the International Global Atmospheric Chemistry (IGAC) programme was initiated in 1990 in collaboration with the Global Atmosphere Watch (GAW) network of the World Meteorological Organisation (WMO) to investigate long-term concentrations and deposition (wet and dry) of atmospheric biogeochemical species (mainly $\mathrm{C}, \mathrm{N}$ and $\mathrm{S}$ species) for regions in the tropics for which limited long-term datasets exist (Lacaux et al., 2003). The African component of this initiative is known as IGAC DEBITS Africa (IDAF), and consists of ten strategically positioned deposition sites in southern and western Africa that are representative of important African ecosystems (IDAF, 2011). Four of the South African IDAF sites are situated in the north-eastern interior of South Africa, i.e. Louis Trichardt, Amersfoort, Skukuza and the Vaal Triangle, as indicated in Fig. 1. These sites are considered to represent semi-arid and savanna ecosystems. In addition, the coastal Cape Point (CPT) Global Atmosphere Watch (GAW) station, located on the most south-western tip of South Africa (Fig. 1), was also included in the IDAF network in 1995. GAW is a global atmospheric observation network with the main aim to monitor long-term trends in the chemical composition and selected physical parameters of the atmosphere (GAWSIS; Brunke et al., 2004). CPT GAW is a southern-hemispherical background station that is mainly influenced by the maritime sector, but also occasionally by the urban-continental sector. Although the primary objective of CPT GAW is the monitoring of greenhouse gases, various other atmospheric measurements are conducted at the site. The aim of this study was to assess monthly mean long-term seasonal and inter-annual trends of $\mathrm{SO}_{2}, \mathrm{NO}_{2}$ and $\mathrm{O}_{3}$ measured using passive samplers at the CPT GAW atmospheric monitoring station, as well as to determine possible sources of these species based on a 21-year dataset. In addition, the influence of local, regional and global meteorological patterns on the concentrations of these species was also investigated.

\section{Measurement site and experimental methods}

\subsection{Site description}

Detailed site descriptions have been presented by Brunke et al. (2010) and Labuschagne et al. (2018). In short, the CPT GAW station $\left(34^{\circ} 21^{\prime} \mathrm{S}, 18^{\circ} 29^{\prime} \mathrm{E}\right)$ is perched atop a cliff approximately $230 \mathrm{~m}$ above sea-level at the southernmost tip of the peninsula (Fig. 1), resulting in a $300^{\circ}$ ocean view (Brunke et al., 2004). The nearby terrain at the CPT GAW station is predominantly rocky and sparsely vegetated. The site is located within the Cape Floral Region Protected Areas (CFRPA), which has been considered a UNESCO world heritage site since 2004. This region forms part of the Fynbos biome and therefore the local vegetation at CPT GAW is dominated by Fynbos - a fine-leaved, sclerophyllic shrub that is well adapted to a Mediterranean climate (UNESCO, 2015). Although the site is considered to be a Southern Hemispherical marine background site, predominantly impacted by marine air masses, it is also occasionally impacted by air masses passing over the Cape Town metropole that is located approximately $60 \mathrm{~km}$ north of the site (Fig. 1). In addition, the occurrence of biomass burning in the southern parts of Western Cape (mainly the Overberg region) can also have an influence on air masses passing over CPT GAW (Fig. 1).

\subsection{Meteorology}

The local and regional climate in the Western Cape is characterised by moderate temperatures with a distinct wet season occurring from April to September and a dry season from October to March, i.e. a wet winter and a dry summer season (Slemr et al., 2013), which is the exact opposite of dry winters and wet summers experienced in the interior of South Africa (Jaars et al., 2014). In Fig. 2, the average monthly rainfall for the period January 2004 to December 2013 is presented, which clearly indicates the prominent wet and dry seasons in this region. The dry summers in the Western Cape are also characterised by the occurrence of occasional biomass burning events in the surrounding areas. Rain events during winter are mainly associated with cold fronts moving over the region from the south-west. The CPT GAW station experiences predominantly east-south-easterly to south-easterly winds throughout the year (Botha et al., 2018), as indicated by the wind roses compiled for the wet (April to September) and dry (October to March) seasons from 1995 to 2015 in Fig. 2. In addition, the hourly 96-h overlay back trajectories compiled for the wet and dry seasons for entire sampling period (Fig. 1) also indicate that the site is predominantly impacted by air masses passing over the marine background (See Section 2.5). However, the wind roses and back trajectories indicate that CPT GAW is also occasionally impacted by air masses passing over the Cape Town metropole, while the intermittent long-range transport of air masses passing over the industrialised and densely populated northern interior of South Africa is also evident, especially during the wet season. During the dry season, CPT GAW experiences predominantly east-south-easterly to south-easterly winds, which comprise mainly marine air masses influencing CPT GAW. However, during the wet winter season, the frequency of winds originating from the north-north-western to western sector increases, which results in the CPT GAW station being impacted more frequently by air masses passing over the Cape Town conurbation. The overlay back-trajectories also indicate higher frequency of air masses passing over the Cape Town conurbation and South African interior during the winter months.

The global climatic factors considered in this study to possibly influence levels of atmospheric inorganic gaseous species measured at CPT included Total Solar Irradiance (TSI), El-Niño Southern Oscillation (ENSO), the Indian Ocean Dipole (IOD), Quasi-Biennial Oscillation (QBO) and the Southern Annular Mode (SAM). TSI is the main source of energy input into the energy budget of the earth, with even small variations resulting in possible natural forcing with various regional and global responses (IPCC, 2007). ENSO denotes the oscillating sea surface temperatures (SST) observed between the west coast of South America and the International Date Line (Stenseth et al., 2003). Analogous to ENSO, IOD refers to SST differential fluctuations in the tropical western and eastern Indian Ocean, which are strongly connected to various surface wind phenomena in the central area of the Indian Ocean (Saji and Yamagata, 2003; ABM, 2016). QBO depicts the alternating bands of easterly and westerly winds more than $30 \mathrm{~km}$ above the surface of the earth moving downwards through the stratosphere at a rate of approximately $1 \mathrm{~km}$ per month (Baldwin et al., 2001). The zonally symmetrical annular atmospheric circulation structure observed around Antarctica is referred to as SAM. It is characterised by westerly winds that alternately strengthen and weaken in conjunction with fluctuating pressure bands between the mid-to high latitudes of the Southern Hemisphere (Ho et al., 2012).

\subsection{Sampling and analysis}

\subsubsection{Sampling procedure}

Monthly average atmospheric $\mathrm{SO}_{2}, \mathrm{NO}_{2}$ and $\mathrm{O}_{3}$ concentrations were measured with passive samplers for a period of 21 years from January 1995 to December 2015 at CPT GAW. Passive samplers were developed within the framework of the IDAF project at the North-West University, and are based on the passive samplers developed by Ferm (1991). The 


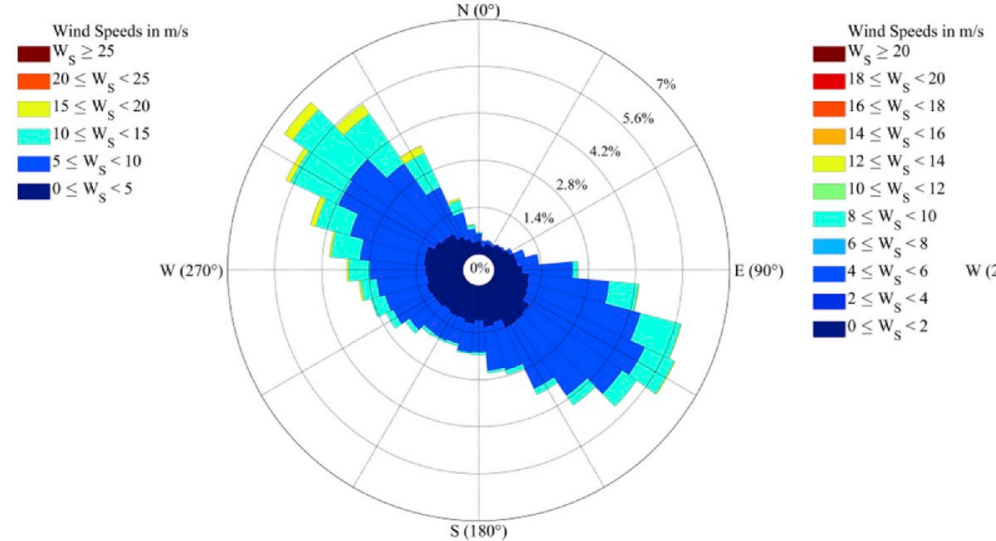

(a)

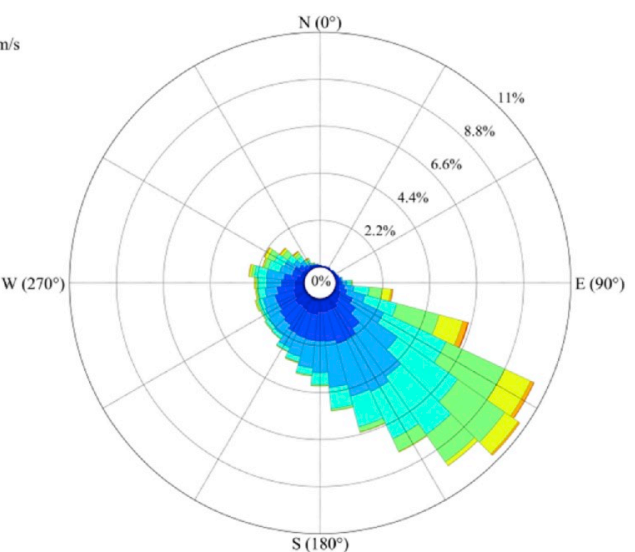

(b)

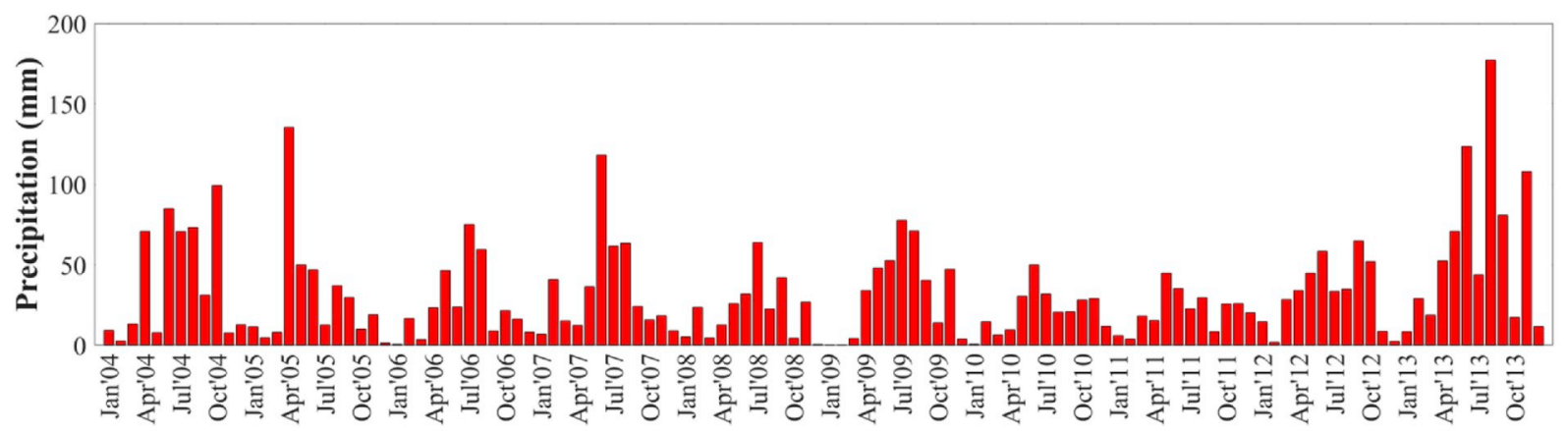

(c)

Fig. 2. (a) Wind direction frequencies during the wet (April to September) and (b) dry seasons (October to March) from 1995 to 2015 , as well as (c) monthly precipitation for the period 2004-2013 at CPT GAW.

theory, functioning and development of these passive samplers have been described in detail in literature (Ferm, 1991; Dhammapala, 1996; Martins et al., 2007; Adon et al., 2010). Briefly, the functioning of the passive samplers is based on laminar diffusion and chemical reaction. The rates at which gases in ambient air diffuse into the sampler are controlled by the diffusion coefficients of the respective gases. In Fig. A1 the composition of passive samplers used in this study is presented, which comprise top and bottom snap-on caps, a support ring, a Teflon filter that prevents internal turbulent diffusion and particle interference, a steel mesh that prevent mechanical damage to the Teflon filter, and a paper filter loaded with an absorbent capable of reacting specifically with the pollutant of interest. The average concentration $\left(\mathrm{C}_{\mathrm{avg}}\right)$ of the gaseous species measured during a sampling period is calculated using Fick's first law of diffusion with the following equation:

$C_{\text {avg }}=\frac{\left(\frac{L}{A}\right) \cdot X}{t \cdot D}$

where $\mathrm{X}$ (mole) is the amount of the pollutant of interest collected on the impregnated filter, $\mathrm{t}(\mathrm{s})$ is the exposure time, $\mathrm{D}\left(\mathrm{m}^{2} \mathrm{~s}^{-1}\right)$ is the diffusion coefficient of the gaseous species of interest in the atmosphere, $L(\mathrm{~m})$ is the diffusion path length, and A $\left(\mathrm{m}^{2}\right)$ is the cross-sectional area of the diffusion path. The average concentration was then converted to ppb.

Passive samplers were prepared at the North-West University and sealed-off in containers prior to sending the samplers to CPT GAW. Preparation in the laboratory included washing and drying of all components of the passive samplers, impregnating paper filters with absorbents and assembling of samplers. The samplers were placed $1.5 \mathrm{~m}$ above ground level, in specially manufactured holders to limit natural interferences. Samplers were exposed in duplicate in order to ensure reproducibility and accuracy, as well as to reduce data loss. The diffusive samplers were exposed for one month, after which the exposed samplers were collected, sealed-off in containers, sent back to the laboratory and stored in a fridge prior to analysis.

$\mathrm{O}_{3}$ levels measured with passive samplers were also compared to active in situ $\mathrm{O}_{3}$ measurements at CPT GAW, which were conducted concurrently during the sampling period with a Thermo Environmental Instruments (TEI 49C) instrument (Oltmans et al., 2013).

\subsubsection{Analysis}

$\mathrm{SO}_{2}, \mathrm{NO}_{2}$ and $\mathrm{O}_{3}$ are captured as sulphate $\left(\mathrm{SO}_{4}^{2-}\right)$, nitrite $\left(\mathrm{NO}_{2}^{-}\right)$and nitrate $\left(\mathrm{NO}_{3}^{-}\right)$, respectively on the impregnated filters of the gaseous passive samplers. Collected samples were extracted from paper filters with ultrapure (Milli-Q) water in an ultrasonic bath for $30 \mathrm{~min}$. Prior to 2008, $\mathrm{SO}_{2}$ and $\mathrm{O}_{3}$ samples were analysed with a Dionex 100 Ion Chromatograph (IC), while $\mathrm{NO}_{2}$ samples were analysed with a Cary $50 \mathrm{uv} / \mathrm{vis}$ spectrometer up until 2012. Analysis with the ICS 100 system were conducted with a $4 \mathrm{~mm}$ AS4A-SC analytical column, while the eluent comprised a mixture of $\mathrm{NaHCO}_{3}$ and $\mathrm{NaCO}_{3}$. UV/vis analysis of $\mathrm{NO}_{2}$ samples entailed adding a diazotising agent to the extracted sample and measurement at $540 \mathrm{~nm} . \mathrm{SO}_{2}$ and $\mathrm{O}_{3}$ samples collected after 2008, and $\mathrm{NO}_{2}$ samples collected after 2012 were analysed with a Dionex ICS-3000 system. The Dionex ICS-3000 is a significantly improved IC system with the state-of-the-art eluent generator enabling the analysis of $\mathrm{NO}_{2}$ samples within a reasonable retention time. Analyses on the Dionex ICS3000 up until 2012 (for $\mathrm{SO}_{2}$ and $\mathrm{O}_{3}$ ) were performed with a $2 \mathrm{~mm} \mathrm{AS}$ 
18 analytical column using an eluent $(\mathrm{KOH})$ generation mode kept constant at $18 \mathrm{mM}$ and a flowrate of $0.360 \mathrm{~mL} \mathrm{~min}^{-1}$. After 2012, $\mathrm{SO}_{2}$ and $\mathrm{O}_{3}$ samples were analysed with a $4 \mathrm{~mm}$ AS15 analytical column, while a $4 \mathrm{~mm}$ AS16 analytical column was used for analysis of $\mathrm{NO}_{2}$ samples. A flow of $1.20 \mathrm{~mL} \mathrm{~min}^{-1}$ and an eluent (KOH) generation mode kept constant at $10 \mathrm{mM}$ was used for analysis of $\mathrm{SO}_{2}, \mathrm{O}_{3}$ and $\mathrm{NO}_{2}$ samples. Standard solutions of ionic species were utilised to perform five-point calibrations in all analytical methods.

\subsubsection{Quality assurance and quality control}

The passive samplers developed by the North-West University and used in this study have been verified through participation in various inter-comparison studies, which is a prerequisite for passive samplers used in the DEBITS programme. Martins et al. (2007) reported various inter-comparison studies performed since the development of the passive samplers in 1994 up until 2003. The most recent evaluation of passive samplers used in this study was an international inter-comparison study that was arranged by the National University of Singapore in 2008. In this evaluation, the precision and accuracy of passive samplers used for the monitoring of $\mathrm{SO}_{2}$ and $\mathrm{NO}_{2}$ by various institutions were determined. The final report indicated that the passive samplers used by the North-West University compared very well with active samplers and, in most instances, had better accuracy than similar samplers used by other institutions (He and Bala, 2008). Furthermore, the analytical laboratory participates in the World Meteorological Organisation (WMO) bi-annual Laboratory Inter-Comparison Study (LIS). Conradie et al. (2016) presented the results of the 50th LIS study conducted in 2014, which indicated that the recovery of each ion in standard samples was between 95 and 105\%.

For each set of samplers, blank samples were kept sealed in the containers. Detection limits for each of the species were calculated from several laboratory blank samples, which were based on the method specified by the WMO in the bi-annual GAW laboratory intercomparison study (LIS). The detection limits calculated for each species were: $0.16 \mathrm{ppm}$ for $\mathrm{SO}_{2} ; 0.03 \mathrm{ppm}$ for $\mathrm{NO}_{2}$; and $0.02 \mathrm{ppm}$ for $\mathrm{O}_{3}$. Only data above detection limits are reported. The dataset was also further refined by applying the Q-test with a $95 \%$ confidence threshold in order to reject possible outliers.

\subsection{Meteorological data, fire frequencies and back trajectory analysis}

Local meteorological data for Cape Point, which include temperature, wind direction and -speed, rain depth and relative humidity were obtained from the South African Weather Services (SAWS). In addition, planetary boundary layer heights were obtained using a global weather forecast model operated by the European Centre for Medium-range Weather Forecasts (ECMWF), as was done by Korhonen et al. (2014). ENSO and QBO data was obtained from the National Oceanic and Atmospheric Administration (NOAA) (NOAA, 2015a; NOAA, 2015b; Conradie et al., 2016). SAM data was obtained from the National Environmental Research Council's British Antarctic Survey (Marshall, 2018). TSI and IOD data was obtained from Koninklijk Nederlands Meteorologisch Instituut (KMNI, 2016a; KMNI, 2016b).

Daily fire distribution data for the period 2000 to 2016 was derived from the National Aeronautics and Space Administration's (NASA) Moderate Resolution Imaging Spectrometer (MODIS) satellite retrievals. MODIS is mounted on the polar-orbiting Earth Observation System's (EOS) Terra spacecraft and globally measures, among others, burn scars, fire and smoke distributions. This dataset was retrieved from the NASA Distributed Active Archive Centres (DAAC) (Kaufman et al., 2003).

The Hybrid Single-Particle Langrangian Integrated Trajectory (HYSPLIT) model version 4.8 developed by the National Oceanic and Atmospheric Administration's (NOAA) Air Resource Laboratory (ARL) was used to determine 96-h back trajectories for the air masses arriving hourly at Cape Point (Draxler and Hess, 2014). The meteorological data applied in this model was obtained from the Global Data Assimilation
System (GDAS) archive of the National Centre for Environmental Prediction (NCEP) of the United States National Weather Service (USNWS). An arrival height of $100 \mathrm{~m}$ was chosen in order to reduce error margins associated with lower arrival heights (Venter et al., 2015). Overlay back trajectory frequency maps were compiled with programmable software. A colour code indicates the percentage of trajectories passing over $0.2^{\circ} \times 0.2^{\circ}$ grid cells with red being the highest percentage of trajectories passing over a specific cell and dark blue the lowest percentage.

\subsection{Multiple linear regression model}

A multiple linear regression (MLR) model was utilised in this study in order to statistically evaluate the influence of local, regional and global meteorological patterns on the atmospheric concentrations of inorganic gaseous species at CPT GAW, which is similar to the Trend-Run model utilised at Reunion University for temperature or ozone trend estimates in the southern tropics (Bencherif et al., 2006; Toihir et al., 2018). The MLR approach allows the decomposition of a series of observed data (such as concentrations of $\mathrm{SO}_{2}, \mathrm{NO}_{2}$ and $\mathrm{O}_{3}$, noted below $\mathrm{C}(\mathrm{t})$ ) into different components related to the environmental (e.g. meteorological parameters) or societal factors (population density) (hereinafter referred to as 'forcings' or 'proxies'), and to estimate their importance. This technique requires an in-depth knowledge of these factors influencing the measurement, each represented by a time series comparable to the one analysed.

The following general equation describes the general decomposition performed:

$C(t)=\sum_{k=1}^{p} a(k) \times f(t, k)+R^{\prime}(t)$

where $f(t, k)$ is the forcing $k$ function of time $t$, and $a(k)$ is the amplitude calculated during the multi-linear regression for $\mathrm{k}$ that minimises the root mean square error (RMSE). The RMSE compares the calculated values with the measured values as follows:

$\chi^{2}=\left[\sum_{t} C(t)-\sum_{k} a(k) \times f(t, k)\right]^{2}$

Therefore, the MLR approach makes it possible to reconstruct the original signal (if all environmental influences have been correctly taken into account) by summing the various calculated contributions. The residual term $\mathrm{R}(\mathrm{t})$ then contains the factors that may influence the measured series, but which were not included in the MLR model, as well as the measurement noise. The quality of the model can be estimated using the sum of the residual squares. The trend was parameterised as linear: Trend $(t)=\alpha_{0}+\alpha_{1} . t$, where $t$ denotes the time range, $\alpha_{0}$ is a constant, $\alpha_{1}$ is the slope of Trend $(\mathrm{t})$ line that estimates the trend over the time scale.

In order to assess the significance of each of the independent variables on the calculated $\mathrm{C}(\mathrm{t}$ ), the relative importance weights (RIW) approach was considered, which examines the relative contribution that each independent variable makes to the dependent variable and ranks independent variables in order of importance (Nathans et al., 2012; Kleynhans et al., 2017). The RIW approach was applied with IBM ${ }^{\circledR}$ SPSS ${ }^{\circledR}$ Statistics Version 23, together with program syntaxes and scripts adapted from Kraha et al. (2012) and Lorenzo-Seva et al. (2010).

\section{Results and discussion}

Since CPT GAW is influenced by air masses from both the maritime sector (on average most of the time), as well as from the urbancontinental sector, it is subjected to contrasting air-chemical regimes. Therefore, in the case of data obtained with passive samplers, the predicament is that the two datasets, i.e. background and non-background, are not separated, but intermingled to varying proportions as a function of seasonality. During the winter months, the urban-continental 
proportion could be as high as $60 \%$, while during the summer months it is often as low as $20 \%$. Therefore, the seasonality observed within the mixed dataset is primarily driven by meteorology, which complicates air-chemical interpretations (Botha et al., 2018; Labuschagne et al., 2018). Therefore, it is important to consider this limitation when interpreting composite concentrations of gaseous species determined with passive samplers at CPT GAW. However, in the absence of any continuously active $\mathrm{SO}_{2}$ and $\mathrm{NO}_{2}$ measurements at CPT GAW, this 21-year passive sampling dataset could be utilised to meaningfully contextualise concentrations of these species, as well as elucidate seasonal patterns and inter-annual variability.

In Fig. A2 the time series of the monthly average $\mathrm{SO}_{2}, \mathrm{NO}_{2}$ and $\mathrm{O}_{3}$ concentrations measured with passive samplers during the 21-year sampling period are presented. In subsequent sections this data series will be evaluated in terms of seasonal and inter-annual variability associated with changes in meteorology and source contributions, as well as statistically assessed with a multiple linear regression model as indicated in Section 2.5.

\subsection{Contextualisation}

In Fig. 3, the atmospheric gaseous concentrations measured at CPT GAW from 1995 to 2015 are compared to the averages of these species also measured with passive samplers at other South African and African IDAF sites. With the exception of Amersfoort, which is in close proximity to industrial sources, all the sites listed in Table 1 are considered to be background sites with no local sources of pollutants (Conradie et al., 2016; Adon et al., 2010; Martins et al., 2007). The average $\mathrm{SO}_{2}$ concentration of $2.9 \mu \mathrm{g} / \mathrm{m}^{3}$ measured at CPT GAW is similar to the average $\mathrm{SO}_{2}$ level determined at background sites located in wet and dry savannahs, i.e. Agoufou $\left(2.6 \mu \mathrm{g} / \mathrm{m}^{3}\right)$, Djougou $\left(2.1 \mu \mathrm{g} / \mathrm{m}^{3}\right)$, Lamto $\left(2.1 \mu \mathrm{g} / \mathrm{m}^{3}\right)$ and Louis Trichardt $\left(2.1 \mu \mathrm{g} / \mathrm{m}^{3}\right)$. The average $\mathrm{SO}_{2}$ concentration at CPT GAW is approximately two times lower than the $\mathrm{SO}_{2}$ level measured at the industrially impacted Amersfoort (Conradie et al., 2016). Much lower $\mathrm{SO}_{2}$ concentrations are measured in the two sites representative of forest ecosystem, i.e. Bomassa $\left(1.0 \mu \mathrm{g} / \mathrm{m}^{3}\right)$ and Zoetele $\left(0.8 \mu \mathrm{g} / \mathrm{m}^{3}\right)$, as well as Okaukuejo $\left(1.0 \mu \mathrm{g} / \mathrm{m}^{3}\right)$ located in a desert. Reported $\mathrm{SO}_{2}$ concentrations at two dry savannah sites in western African dry savannah sites (Katibougou and Banizoumbou) are $\sim 50 \%$ of that measured at CPT GAW $\left(\leq 1.6 \mu \mathrm{g} / \mathrm{m}^{3}\right)$.

The average $\mathrm{NO}_{2}$ concentration of $2.4 \mu \mathrm{g} / \mathrm{m}^{3}$ measured at CPT GAW is close to the mean $\mathrm{NO}_{2}$ levels determined in the wet savannahs at Djougou $\left(2.3 \mu \mathrm{g} / \mathrm{m}^{3}\right)$ and Lamto $\left(1.9 \mu \mathrm{g} / \mathrm{m}^{3}\right)$, as well as in the forest at Bomassa $\left(2.6 \mu \mathrm{g} / \mathrm{m}^{3}\right)$. The average $\mathrm{NO}_{2}$ concentrations at the anthropogenically impacted Amersfoort (Conradie et al., 2016; Martins et al., 2007) in South Africa, i.e. $4.7 \mu \mathrm{g} / \mathrm{m}^{3}$, are approximately two times higher compared to $\mathrm{NO}_{2}$ measured at CPT GAW, while the average $\mathrm{NO}_{2}$ concentration at the South African inland regional background site Louis Trichardt $\left(1.3 \mu \mathrm{g} / \mathrm{m}^{3}\right)$ is approximately two times lower than CPT GAW $\mathrm{NO}_{2}$ levels. Mean $\mathrm{NO}_{2}$ levels measured for the dry savannahs in western Africa, i.e. Agoufou $\left(3.4 \mu \mathrm{g} / \mathrm{m}^{3}\right)$, Katibougou $\left(3.6 \mu \mathrm{g} / \mathrm{m}^{3}\right)$ and Banizoumbou $\left(4.5 \mu \mathrm{g} / \mathrm{m}^{3}\right)$ were higher than $\mathrm{NO}_{2}$ measured at CPT GAW, which were similar to $\mathrm{NO}_{2}$ concentrations measured at Amersfoort and mainly attributed to the impacts of biomass burning in this region (Adon et al., 2010). Much lower average $\mathrm{NO}_{2}$ concentrations are observed for the arid Okaukuejo site $\left(0.6 \mu \mathrm{g} / \mathrm{m}^{3}\right)$, which can be attributed to low microbial activity (Ludwig et al., 2001; Hénault et al., 2005; Adon et al., 2010) and no nearby anthropogenic sources.

The average $\mathrm{O}_{3}$ concentrations measured with passive samplers at CPT GAW $\left(52.0 \mu \mathrm{g} / \mathrm{m}^{3}\right)$ for the 21-year dataset were similar to the average $\mathrm{O}_{3}$ levels determined from relatively long-term ( $\sim 10$ years) passive sampling datasets at the southern African sites Amersfoort $\left(53.0 \mu \mathrm{g} / \mathrm{m}^{3}\right)$ and Okaukuejo $\left(45.1 \mu \mathrm{g} / \mathrm{m}^{3}\right)$, but lower than the average $\mathrm{O}_{3}$ concentration at Louis Trichardt $\left(68.7 \mu \mathrm{g} / \mathrm{m}^{3}\right)$ from 1995 to 2005 . The passive sampling-derived average $\mathrm{O}_{3}$ concentration were also similar to the average of active in situ $\mathrm{O}_{3}$ measurements conducted at CPT GAW during the 21 -year passive sampling period, i.e. $49.3 \mu \mathrm{g} / \mathrm{m}^{3}$. These average $\mathrm{O}_{3}$ levels measured at the southern African sites are approximately two times higher than the mean $\mathrm{O}_{3}$ concentrations measured for dry savannahs at Agoufou $\left(23.5 \mu \mathrm{g} / \mathrm{m}^{3}\right)$, Katibougou
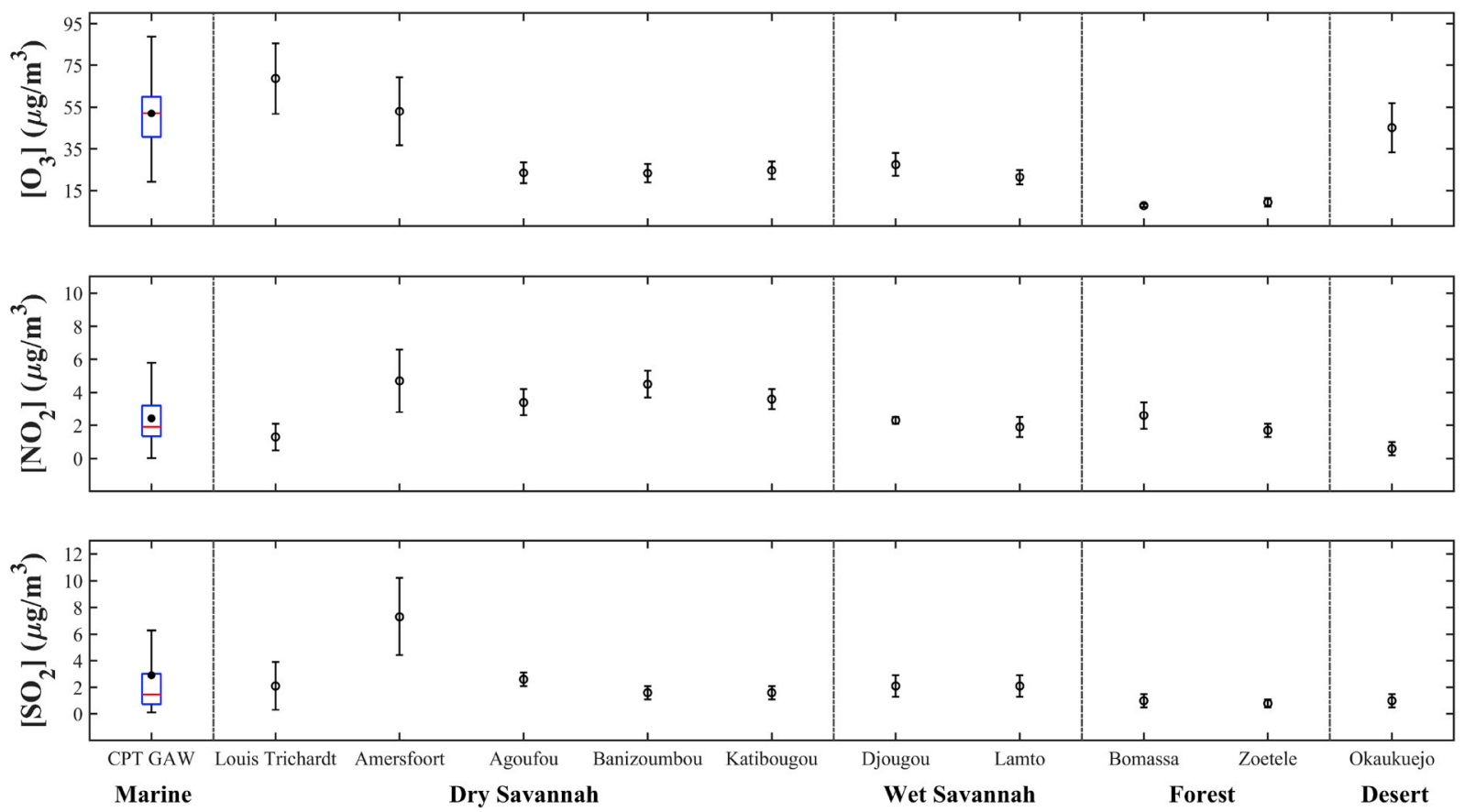

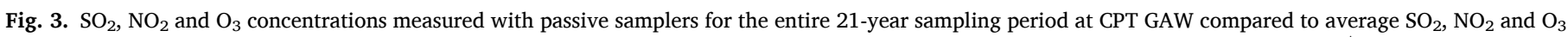

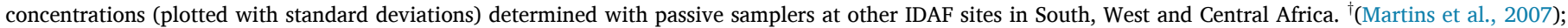

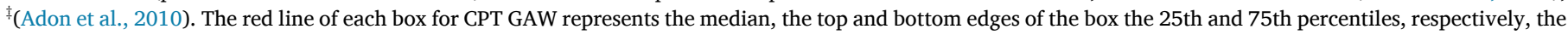

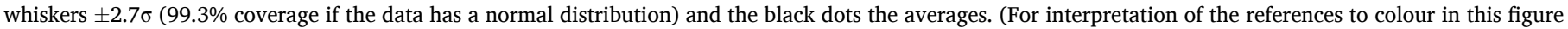
legend, the reader is referred to the Web version of this article.) 
Table 1

Regression coefficients and relative important weight percentage (RIW\%) of each independent variable included in the $\mathrm{MLR}$ model to calculate $\mathrm{SO}_{2}, \mathrm{NO}_{2}$ and $\mathrm{O}_{3}$ concentrations.

\begin{tabular}{|c|c|c|c|c|c|c|c|c|}
\hline \multicolumn{3}{|l|}{$\underline{\mathrm{SO}}_{2}$} & \multicolumn{3}{|l|}{$\underline{\mathrm{NO}}_{2}$} & \multicolumn{3}{|l|}{$\underline{\mathrm{O}}_{3}$} \\
\hline & $b$ & RIW\% & & $b$ & RIW\% & & $b$ & RIW\% \\
\hline \multicolumn{9}{|c|}{ i) Global forcing factors } \\
\hline TSI & -3.791 & 81.3 & TSI & -1.167 & 74.2 & IOD & 5.237 & 43.7 \\
\hline ENSO & -0.856 & 9.7 & IOD & 0.708 & 11.9 & SAM & -0.605 & 28.5 \\
\hline IOD & 1.741 & 6.9 & QBO & -0.011 & 6.2 & QBO & -0.076 & 22.0 \\
\hline SAM & -0.089 & 1.1 & SAM & 0.091 & 6.0 & TSI & 1.065 & 2.9 \\
\hline QBO & -0.013 & 1.0 & ENSO & -0.134 & 1.8 & ENSO & -0.312 & 2.9 \\
\hline \multicolumn{9}{|c|}{ ii) Global, regional and local factors } \\
\hline TSI & -4.666 & 60.3 & CAM & 0.033 & 12.7 & $\mathrm{~T}$ & -3.390 & 33.5 \\
\hline ENSO & -0.506 & 5.3 & RH & 0.023 & 12.4 & $\mathrm{CO}$ & 0.182 & 21.2 \\
\hline IOD & 1.907 & 5.2 & Ws & -0.671 & 11.4 & CAM & 0.179 & 10.5 \\
\hline $\mathrm{T}$ & 0.537 & 4.3 & $\mathrm{P}$ & $1.995 \times 10^{-5}$ & 11.4 & $\mathrm{RH}$ & $-7.237 \times 10^{-3}$ & 10.2 \\
\hline Ws & 0.762 & 4.2 & $\mathrm{CO}_{2}$ & -0.716 & 10.8 & LFE & $-3.606 \times 10^{-3}$ & 5.1 \\
\hline OAM & -0.021 & 3.9 & TSI & -0.520 & 7.8 & DFE & $-1.063 \times 10^{-4}$ & 3.0 \\
\hline $\mathrm{P}$ & $3.598 \times 10^{-5}$ & 3.8 & IOD & 1.345 & 5.8 & Wd & -0.018 & 2.8 \\
\hline $\mathrm{CO}_{2}$ & -1.427 & 3.8 & DFE & $-3.370 \times 10^{-4}$ & 5.7 & OAM & 0.071 & 2.5 \\
\hline CAM & 0.048 & 1.9 & OAM & $-6.133 \times 10^{-3}$ & 3.4 & $\mathrm{RH}$ & 0.067 & 2.4 \\
\hline $\mathrm{CO}$ & 0.040 & 1.8 & QBO & -0.013 & 3.0 & PBL & $1.910 \times 10^{-3}$ & 2.2 \\
\hline Wd & $5.723 \times 10^{-3}$ & 1.5 & $\mathrm{CO}$ & 0.017 & 2.8 & IOD & 0.476 & 1.4 \\
\hline SAM & -0.093 & 0.8 & $\mathrm{~T}$ & 0.159 & 2.6 & Ws & -0.072 & 1.3 \\
\hline $\mathrm{RH}$ & $9.503 \times 10^{-3}$ & 0.8 & ENSO & -0.303 & 2.3 & SAM & -0.467 & 1.1 \\
\hline PBL & $3.382 \times 10^{-4}$ & 0.8 & Wd & $-7.963 \times 10^{-4}$ & 2.3 & $\mathrm{P}$ & $2.089 \times 10^{-5}$ & 1.1 \\
\hline QBO & $-4.310 \times 10^{-3}$ & 0.5 & PBL & $-7.967 \times 10^{-4}$ & 2.3 & $\mathrm{CO}_{2}$ & -0.728 & 0.9 \\
\hline $\mathrm{RH}$ & -0.067 & 0.4 & SAM & 0.096 & 1.5 & QBO & -0.012 & 0.5 \\
\hline $\mathrm{DFE}$ & $2.533 \times 10^{-4}$ & 0.4 & $\mathrm{RH}$ & -0.098 & 1.1 & ENSO & -0.990 & 0.2 \\
\hline LFE & $-4.537 \times 10^{-4}$ & 0.3 & LFE & $5.436 \times 10^{-4}$ & 0.7 & TSI & $-1.275 \times 10^{-3}$ & 0.1 \\
\hline
\end{tabular}

$\left(24.7 \mu \mathrm{g} / \mathrm{m}^{3}\right)$ and Banizoumbou $\left(23.3 \mu \mathrm{g} / \mathrm{m}^{3}\right)$, as well as for wet savannahs at Djougou $\left(27.5 \mu \mathrm{g} / \mathrm{m}^{3}\right)$ and Lamto $\left(21.4 \mu \mathrm{g} / \mathrm{m}^{3}\right)$ in western Africa. Much lower average $\mathrm{O}_{3}$ concentrations were measured for forest ecosystems at Bomassa $\left(7.8 \mu \mathrm{g} / \mathrm{m}^{3}\right)$ and Zoetele $\left(9.4 \mu \mathrm{g} / \mathrm{m}^{3}\right)$ in central Africa. The relatively high $\mathrm{O}_{3}$ concentrations measured at CPT GAW also reflect the regional $\mathrm{O}_{3}$ problem in southern Africa (Laban et al., 2018). $\mathrm{O}_{3}$ concentrations in southern Africa can be attributed to a combination of regional impacts, which include industrial, vehicular, and domesticand open biomass burning emissions that are often re-circulated through anti-cyclonic air mass processes (Laban et al., 2018). The higher $\mathrm{O}_{3}$

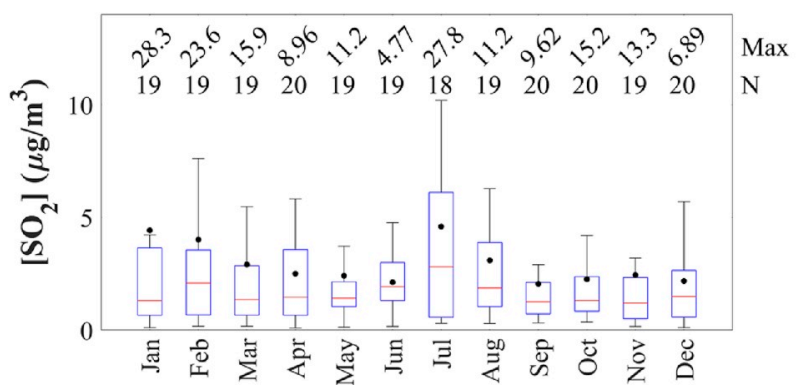

(a)

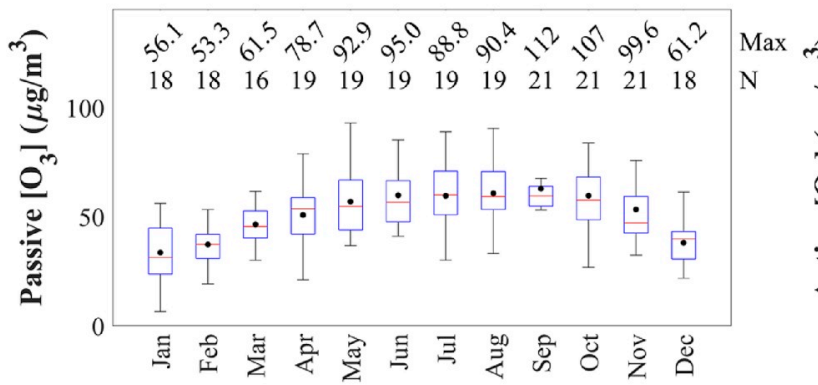

(c)

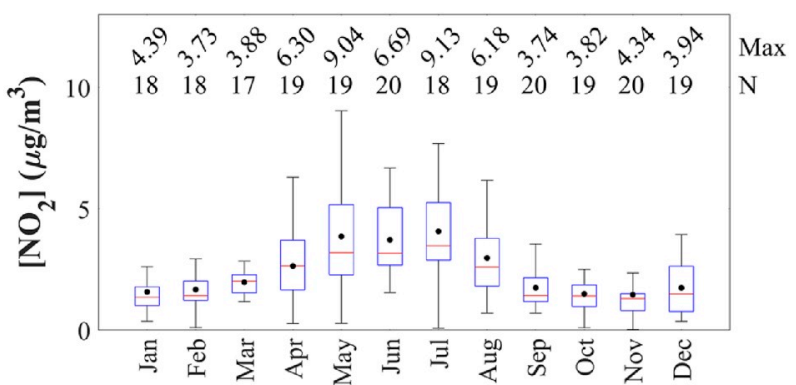

(b)

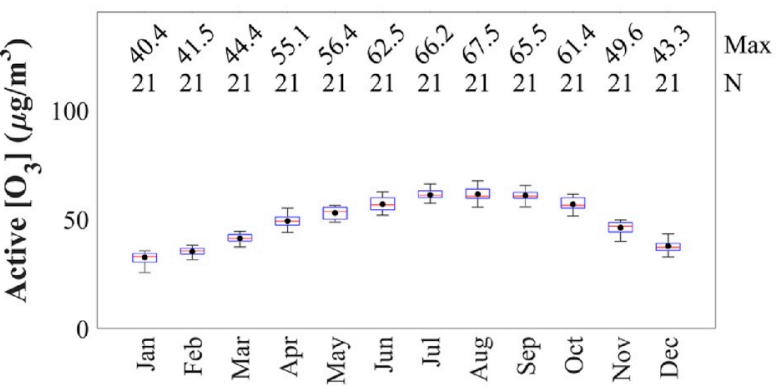

(d)

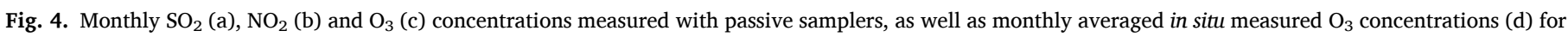

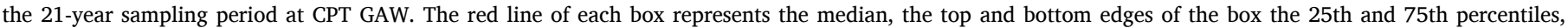

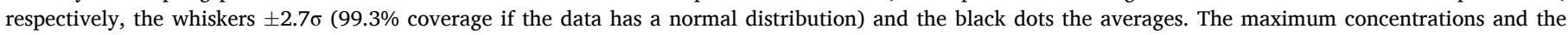

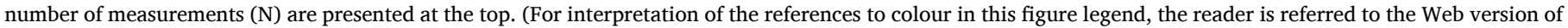
this article.) 
concentration measured at Louis Trichardt can be ascribed to the additional influence of trans-boundary impacts from biomass burning events in sub-Saharan Africa, especially Mozambique, Zambia, Zimbabwe and Angola (Tiitta et al., 2014), as well as biomass burning occurring over the central African region (e.g. Democratic Republic of Congo) (Swapt et al., 2003).

\subsection{Seasonal patterns}

In Fig. 4, the monthly concentrations for each of the gaseous species measured for the entire sampling period are presented. A few instances are observed where the average monthly concentrations were similar to or exceeded the 75th percentiles. These occurrences were attributed to monthly concentrations for specific years being significantly higher, which were not identified as outliers by the Q-test (Fig. A2). $\mathrm{SO}_{2}$ did not reveal a clear seasonal pattern, although higher $\mathrm{SO}_{2}$ concentrations were observed during two periods in the year, i.e. January to February, and July to August. More distinct seasonal patterns were observed for $\mathrm{NO}_{2}$ and $\mathrm{O}_{3}$. Higher $\mathrm{NO}_{2}$ levels occurred from April to August with $\mathrm{NO}_{2}$ concentrations peaking between May and August, while $\mathrm{O}_{3}$ had higher concentrations between July and October. The seasonal $\mathrm{NO}_{2}$ and $\mathrm{O}_{3}$ patterns is also reflected in the time series, while the less distinct trend in monthly $\mathrm{SO}_{2}$ concentrations is also evident for the 21-year time series (Fig. A2). It is also apparent from the time series that significantly higher $\mathrm{SO}_{2}$ concentrations measured in 2009 and 2011 (especially in 2009) contributed to box-and-whisker plots of monthly $\mathrm{SO}_{2}$ concentration having a larger range in July, as well as contributed to monthly average $\mathrm{SO}_{2}$ levels exceeding the 75th percentiles in January and February (Fig. 4(a)). Significantly higher $\mathrm{SO}_{2}$ concentrations were also measured in January 2008 and February 2003. Comparison of the passively derived $\mathrm{O}_{3}$ concentrations with in-situ measurements revealed a similar seasonal pattern with relatively good agreement between monthly mean and median values for the 21-year sampling period. In Fig. A3, the time series of the $\mathrm{O}_{3}$ concentrations determined with passive samplers and insitu measurements are presented, which also indicate good correlations between the two measurement techniques. In addition, a correlation plot between passively derived $\mathrm{O}_{3}$ concentrations and in-situ measurements indicate a very good correlation (0.89) between these two measurement techniques as indicated in Fig. A4. Differences between passive-derived $\mathrm{O}_{3}$ concentrations and in-situ measurements can be attributed to the functioning of the passive $\mathrm{O}_{3}$ sampler in which $\mathrm{O}_{3}$ is indirectly measured through the oxidation of $\mathrm{NO}_{2}^{-}$to $\mathrm{NO}_{3}^{-}$by $\mathrm{O}_{3}$. Other atmospheric oxidants could contribute to higher $\mathrm{O}_{3}$ concentrations determined with passive samplers. In addition, fluctuations in relative humidity can also contribute to variability in $\mathrm{O}_{3}$ levels measured with passive samplers, since the oxidation of $\mathrm{NO}_{2}^{-}$to $\mathrm{NO}_{3}^{-}$is enhanced by the presence of water molecules. Lower concentrations measured with passive samplers are usually attributed to decreased diffusion of the pollutant mainly associated with higher wind speeds, while lower relative humidity could also contribute to less effective reaction with $\mathrm{NO}_{2}^{-}$. In an effort to explain the observed seasonal patterns for $\mathrm{SO}_{2}, \mathrm{NO}_{2}$ and $\mathrm{O}_{3}$, seasonal changes in meteorological conditions, source contributions and ecological process were considered.

As indicated in Section 2.2, overlaid back trajectories (Fig. 1) and wind roses (Fig. 2) compiled for the wet and dry seasons revealed that inorganic gas concentrations measured during the dry season generally represent Southern Hemispheric background levels CPT GAW, while the higher frequency of air masses passing over the Cape Town conurbation and South African interior during the wet winter months is evident. Botha et al. (2018) also attributed higher radon concentrations at CPT GAW (based on 15-year radon measurements) in winter months to an increase in frequency of air masses passing over the continental surface, compared to summer when CPT GAW is more frequently impacted by oceanic air masses. In addition, the monthly carbon monoxide (CO) concentrations at CPT GAW were also indicative of the increased anthropogenic influences from the continent during winter as indicated by higher $\mathrm{CO}$ levels measured during winter (Fig. A5). Therefore, the higher $\mathrm{SO}_{2}$ concentrations observed in July and August, as well as the higher $\mathrm{NO}_{2}$ levels occurring from April to August, can be partially attributed to an increase in frequency of air masses moving over Cape Town to CPT GAW. Typical sources of $\mathrm{SO}_{2}$ and $\mathrm{NO}_{2}$ in the Cape Town conurbation include industrial activities, vehicular emissions, as well as household combustion for cooking and space heating (Ojumu, 2013). In addition, household combustion for space heating will increase during the colder winter months, while more pronounced inversion layers during winter will trap pollutant species near the surface that will lead to higher concentrations of pollutant species in the Cape Town conurbation during winter influencing CPT GAW. Cape Town is also characterised by the occurrence of brown haze events during winter, which is attributed to the build-up of pollutant concentrations within strong inversion layers (Wicking-Baird et al., 1997). The wet season overlay back trajectories also indicate the possible influence of the long-range transport of atmospheric pollutants from the industrialised Highveld in the north-eastern interior of South Africa (Ojumu, 2013; Abiodun et al., 2014). However, it is difficult to quantify the influence of up-country circulation on CPT GAW measurements due to these air masses being obscured by the Cape Town conurbation signal (especially for monthly averages determined with passive samplers), as well as atmospheric residence times of $\mathrm{NO}_{2}$ and $\mathrm{SO}_{2}$.

The initial seasonal increase in $\mathrm{NO}_{2}$ concentrations at CPT GAW also coincides with the onset of the wet season in April. This indicates that $\mathrm{NO}_{2}$ levels can partially be associated with the emissions of biogenic nitrogen (N) accumulated in the soil (Adon et al., 2010). CPT GAW is situated in a nature reserve where $\mathrm{N}$ species from, e.g. guano from the sea birds, can accumulate in the soil during the dry season. After the first rain event occurs, bacterial nitrification is activated, which leads to $\mathrm{N}$ consumption that causes the release of large pulses of NO (Ludwig et al., 2001; Hénault et al., 2005; Adon et al., 2010) that is rapidly oxidised to $\mathrm{NO}_{2}$. In addition, since the passive samplers were deployed relatively close to the surface $(1.5 \mathrm{~m})$, passive sampling measurements are exposed to surface effects (soil-nitrogen chemistry), especially under calm winter conditions. Therefore, microbial activity could also contribute to the observed increased $\mathrm{NO}_{2}$ concentrations at CPT GAW during the wet winter season.

As mentioned, $\mathrm{O}_{3}$ exhibited a seasonal trend similar to $\mathrm{NO}_{2}$, with $\mathrm{O}_{3}$ concentrations also gradually increasing from April. Since atmospheric $\mathrm{O}_{3}$ is a secondary pollutant formed through the photochemical oxidation of $\mathrm{NO}_{2}, \mathrm{O}_{3}$ production can be driven by increased $\mathrm{NO}_{2}$ emissions into the atmosphere. However, $\mathrm{O}_{3}$ production has a complex and non-linear dependence on precursor emissions, which also include volatile organic compounds (VOCs) and CO (e.g. NRC (1991)). The monthly CO concentrations determined with in-situ measurements at CPT GAW during the sampling period also displayed a similar seasonal pattern to $\mathrm{O}_{3}$ and $\mathrm{NO}_{2}$ (Fig. A5). $\mathrm{O}_{3}$ production is generally classified as being either VOC- or $\mathrm{NO}_{\mathrm{x}}$-limited. In a $\mathrm{NO}_{\mathrm{x}}$-limited $\mathrm{O}_{3}$ production regime, $\mathrm{O}_{3}$ concentrations will increase with increasing $\mathrm{NO}_{\mathrm{x}}$ concentrations, which is typical for background regions with low $\mathrm{NO}_{\mathrm{x}}$ emissions (Laban et al., 2018). Therefore, the increase in $\mathrm{O}_{3}$ concentrations coinciding with increased $\mathrm{NO}_{2}$ concentrations can be expected at CPT GAW. Adon et al. (2010) indicated a similar observation for dry (semi-arid) savannahs in West Africa, where $\mathrm{NO}_{2}$ and $\mathrm{O}_{3}$ levels were also higher during the wet season, while Stewart et al. (2008) also estimated a relatively high $\mathrm{O}_{3}$ production rate as a result of high $\mathrm{NO}_{\mathrm{X}}$ concentrations during the AMMA experiment in the Sahel. $\mathrm{O}_{3}$ levels remained relatively high at the end of the wet season during August and September, while $\mathrm{NO}_{2}$ concentrations decreased. This can be attributed to reduced $\mathrm{O}_{3}$ titration through reaction with $\mathrm{NO}_{2}$, while August and September are also associated with increased photochemical oxidation due to longer daylight hours in spring. Although daylight hours are even longer during the summer months, $\mathrm{O}_{3}$ concentrations remain relatively low during summer due to fewer precursor species in the atmosphere, and CPT GAW being impacted more frequently by oceanic air mass. 
Biomass burning is considered to be a major source of pollutant species (e.g. $\mathrm{NO}_{2}$ and $\mathrm{O}_{3}$ ) in the interior of South Africa (Vakkari et al., 2013). Therefore, the impacts of local and regional biomass burning on the concentrations of the gaseous species measured were also investigated. In Fig. 5, the monthly average burn frequency for southern Africa from 2000 to 2016, as well as the burn frequency within a $400 \mathrm{~km}$ radius from the CPT GAW for the same period obtained from MODIS satellite data is presented. It is evident that the burn frequency is generally higher from June to October in South Africa, peaking in September, which is associated with the dry season in the interior of South Africa. However, limiting the burn frequency within a $400 \mathrm{~km}$ radius of the CPT GAW indicates higher burn frequencies coinciding with the dry season in the Western Cape. It is evident from the wind rose compiled for the dry season in Fig. 2 and the $400 \mathrm{~km}$ radius surrounding CP GAW indicated in Fig. 1(a) that winds arriving at the CPT GAW during this period coincide with air masses passing over the Overberg district, which is a large area covered by natural vegetation that is susceptible to biomass burning during the dry season (Brunke et al., 2001). This area also houses two South African national parks, i.e. the Agulhas- and Bontebok National Parks. Furthermore, the continental flow of air masses indicated by overlay back trajectories (Fig. 1(b)) also reflects the possible impact of biomass burning during the dry season on CPT GAW. However, in this study, increased $\mathrm{NO}_{2}$ and $\mathrm{O}_{3}$ concentrations, typically associated with biomass burning in South Africa (Lourens et al., 2011; Laban et al., 2018), are not observed at CPT GAW. Higher $\mathrm{SO}_{2}$ concentrations in January and February did, however, coincide with increased biomass burning. $\mathrm{SO}_{2}$ emissions are not generally associated with biomass burning and are not well quantified. Although Adon et al. (2010) did consider biomass burning a source of $\mathrm{SO}_{2}$ at western African savannah background sites, $\mathrm{SO}_{2}$ concentrations were low, while biomass burning also coincided with increased $\mathrm{NO}_{2}$ levels. Therefore, higher $\mathrm{SO}_{2}$ concentrations at CPT GAW measured during January and February are more likely associated with CPT GAW being more frequently impacted by oceanic air masses and oceanic $\mathrm{SO}_{2}$ sources, e.g. oxidation of dimethyl sulphide (DMS).

\subsection{Inter-annual variability}

In Fig. 6, the annual $\mathrm{SO}_{2}, \mathrm{NO}_{2}$ and $\mathrm{O}_{3}$ for the entire sampling period are presented. Small inter-annual variability and a marginal decline are observed for $\mathrm{SO}_{2}$ from 1995 to 2004, while from 2005 to 2009, a steady increase in average annual $\mathrm{SO}_{2}$ concentrations is observed, with $\mathrm{SO}_{2}$ levels reaching an annual average maximum in 2009. The annual average $\mathrm{NO}_{2}$ concentrations declined from 1996 to 2002, after which the annual average $\mathrm{NO}_{2}$ levels steadily increased reaching a maximum in 2011 , with the exception of 2008-2010, during which $\mathrm{NO}_{2}$ levels were relatively lower. Three-year moving averages of the annual average

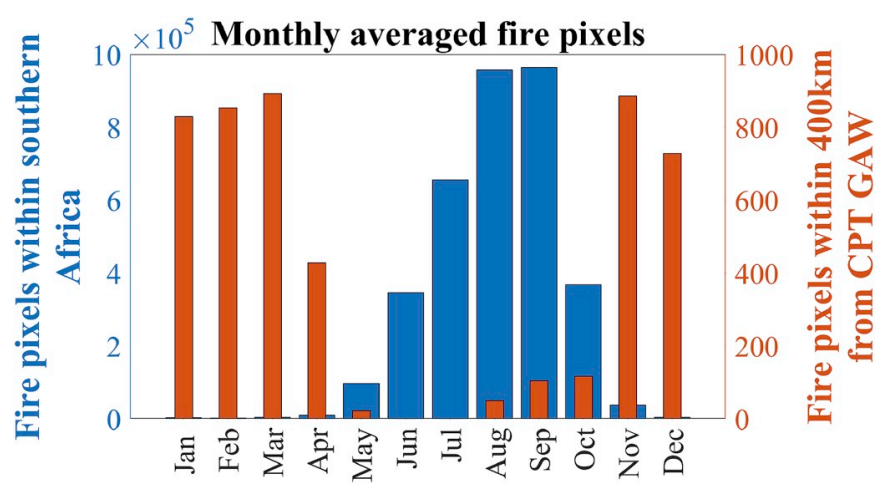

Fig. 5. Average monthly fire pixels for the period 2000 to 2016 within the entire southern Africa (10-35 $\mathrm{S}$ and 10 to $41^{\circ} \mathrm{E}$ ), as well as fire pixels within a radius of $400 \mathrm{~km}$ around CPT GAW. Data obtained from MODIS collection 5 burned area product (Roy et al., 2008) for the period 2000 to 2016. concentrations of $\mathrm{SO}_{2}$ and $\mathrm{NO}_{2}$ indicate a decline in concentrations of both these species from 1996 to 2002, followed by a period of gradual increases in the levels of these species after 2002. The significantly larger range of the 25th and 75th percentiles, as well as average of $\mathrm{SO}_{2}$ levels measured in 2009 (Fig. 6(a)) can be attributed to substantially higher $\mathrm{SO}_{2}$ concentrations measured in January, February and July as indicated by the time series in Fig. A2, which can be considered incidental variances in the dataset. The observed inter-annual variations in $\mathrm{SO}_{2}$ and $\mathrm{NO}_{2}$ concentrations can be attributed to changes in meteorological conditions and/or fluctuations in source contribution, e.g. economic growth associated with increased energy demand and a larger vehicular fleet. Conradie et al. (2016), for instance, indicated that rain samples collected from 2009 to 2014 at the IDAF sites in the north-eastern interior of South Africa had higher $\mathrm{SO}_{4}^{2-}$ and $\mathrm{NO}_{3}^{-}$concentrations compared to rain samples collected in 1986-1999 and 1999 to 2002, which were attributed to the increase in economic growth and higher energy demand as indicated by the increase in electricity consumption in South Africa by Inglesi-Lotz and Blignaut (2011). Furthermore, monthly $\mathrm{SO}_{2}$ and $\mathrm{NO}_{2}$ measurements conducted at the IDAF sites in the north-eastern interior of South Africa also indicate increases in $\mathrm{SO}_{2}$ and $\mathrm{NO}_{2}$ levels from 2001/2002 (Conradie et al., 2016). The inter-annual variability of $\mathrm{SO}_{2}$ and $\mathrm{NO}_{2}$ will be explored further in the subsequent section.

Although the annual $\mathrm{O}_{3}$ concentrations determined with passive samplers indicate inter-annual fluctuations, in-situ measurements of $\mathrm{O}_{3}$ levels do not show significant inter-annual variability. As indicated in section 3.2, the functioning of the $\mathrm{O}_{3}$ passive sampler relies on the measurement of the oxidation potential of the atmosphere (oxidation of $\mathrm{NO}_{2}^{-}$to $\mathrm{NO}_{3}^{-}$), which is also dependent on the presence of water. Therefore, the occurrence of other atmospheric oxidants can contribute to the higher $\mathrm{O}_{3}$ concentrations determined with passive samplers, while lower relative humidity can result in the measurement of lower $\mathrm{O}_{3}$ concentrations. Although Fig. A3 and A4 indicated relatively a good correlation between passive and in situ measurements of $\mathrm{O}_{3}$ during the 21-year sampling period, there are instances and certain years (e.g. 1995 to 1997) for which $\mathrm{O}_{3}$ concentrations measured with the two sampling techniques differed, which results in the observed inter-annual fluctuations determined with passive samplers. Therefore, from the in-situ measurements, it can be deduced that $\mathrm{O}_{3}$ levels at CPT GAW did not reveal any significant inter-annual variability over the sampling period.

\subsection{Modelled variability and linear trend estimates}

In an effort to further explore the above-mentioned variability (seasonal and inter-annual) observed for $\mathrm{SO}_{2}, \mathrm{NO}_{2}$ and $\mathrm{O}_{3}$, a MLR model was developed in order to statistically evaluate the influence of local, regional and global meteorological patterns on the atmospheric inorganic gaseous species concentrations at CPT GAW. Population data, which was obtained from three separate national censuses, was also included in the model as a proxy for increased anthropogenic activities. Local and regional factors considered in the model included wind speed (Ws), wind direction (Wd), ambient temperature (T), rain depth (R), relative humidity $(\mathrm{RH})$, planetary boundary layer height (PBL), CO and carbon dioxide $\left(\mathrm{CO}_{2}\right)$ concentrations, local fire events within $100 \mathrm{~km}$ from site (LFE), regional fire events between $100 \mathrm{~km}$ and $400 \mathrm{~km}$ from site (DFE), and Cape Town metropolitan population (P). Radon data from CPT GAW was used to separate oceanic- (OAM) and continental air mass (CAM) (Botha et al., 2018), which was also included in the model. Global factors considered included TSI, IOD, ENSO, QBO and SAM, as indicated in section 2.2. Although it is recognised that more factors could be considered as input parameters in the model, these global factors were considered to be the most relevant, while the local and regional parameters included were the most complete datasets that could be acquired at CPT GAW. The initial input parameters for the model only included the global force factors for the 21-year sampling period, after which local, regional and global factors were included in 


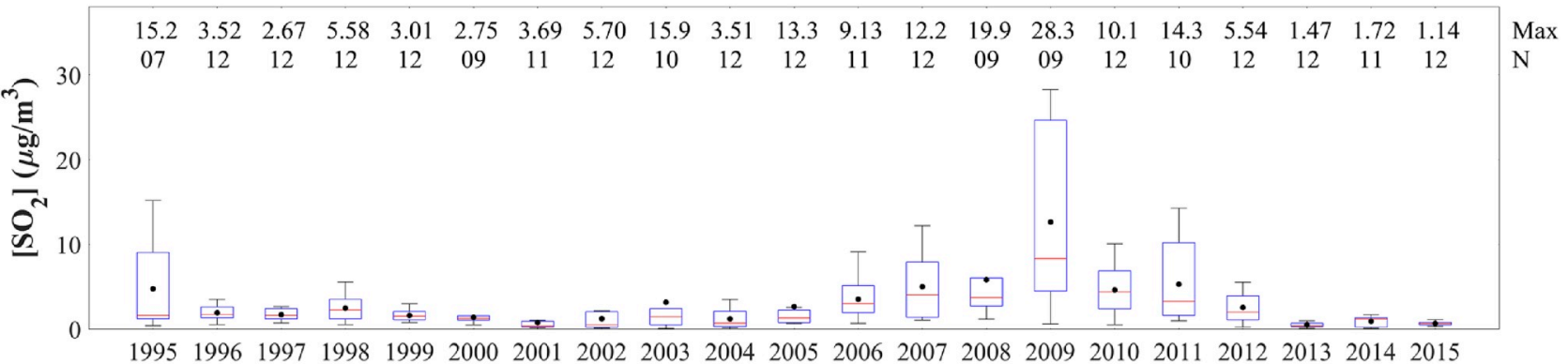

(a)

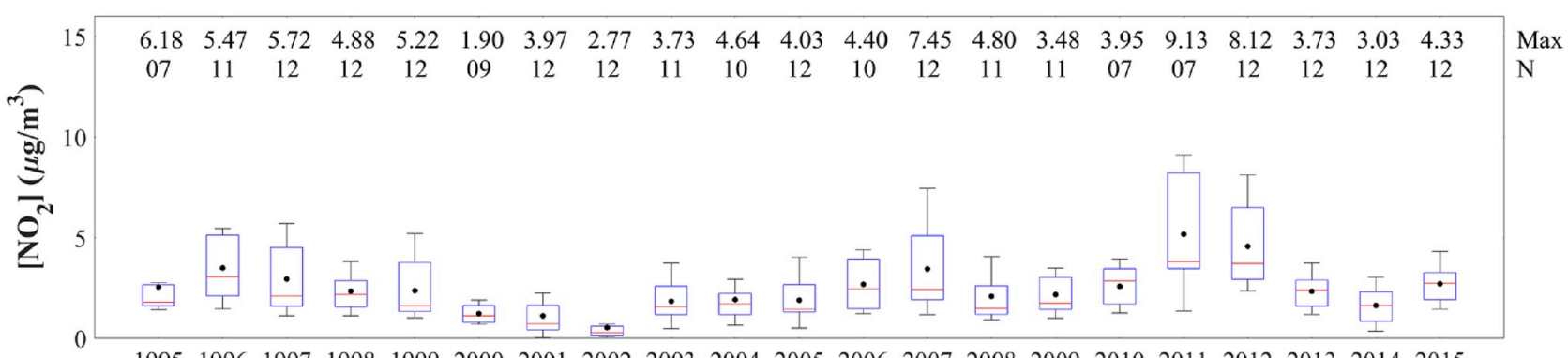

199519961997199819992000200120022003200420052006200720082009201020112012201320142015

(b)

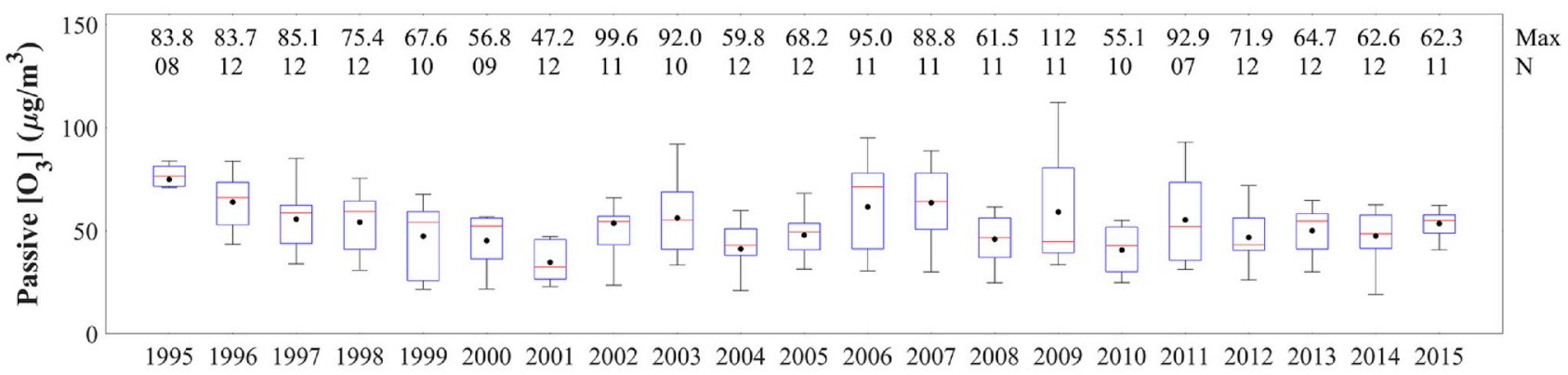

(c)

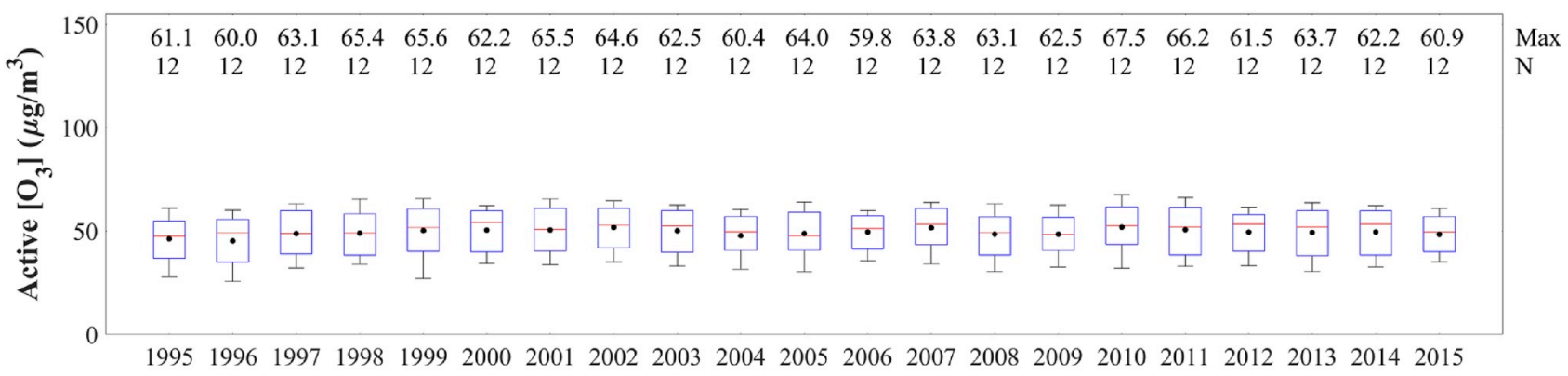

(d)

Fig. 6. Annual $\mathrm{SO}_{2}$ (a), $\mathrm{NO}_{2}$ (b) and $\mathrm{O}_{3}$ (c) concentrations from 1995 to 2015, as well as the annual $\mathrm{O}_{3}$ concentrations determined with in situ measurements (d) at CPT GAW. The red line of each box represents the median, the top and bottom edges of the box the 25th and 75th percentiles, respectively, the whiskers $\pm 2.7 \sigma$ (99.3\% coverage if the data has a normal distribution) and the black dots the averages. The maximum concentrations and the number of measurements (N) are presented at the top. (For interpretation of the references to colour in this figure legend, the reader is referred to the Web version of this article.)

the model for a 15 -year period (from 2000). Since data was not available for certain local and regional factors considered in the model for the entire sampling period, and in order to include the optimum number of local and regional factors available for CPT GAW, modelled concentrations could not be calculated for the entire 21-year sampling period when global, regional and local factors were included.
The modelled $\mathrm{SO}_{2}, \mathrm{NO}_{2}$ and $\mathrm{O}_{3}$ concentrations are related to the measured $\mathrm{SO}_{2}, \mathrm{NO}_{2}$ and $\mathrm{O}_{3}$ levels in Figs. 7-9, respectively through the RMSE differences between the modelled and measured concentrations ((a) and (b)), as well as by comparison between the modelled and measured data time series ((c)). In each of these figures, (a) presents the RMSE differences when only global factors are included, while (b) show 


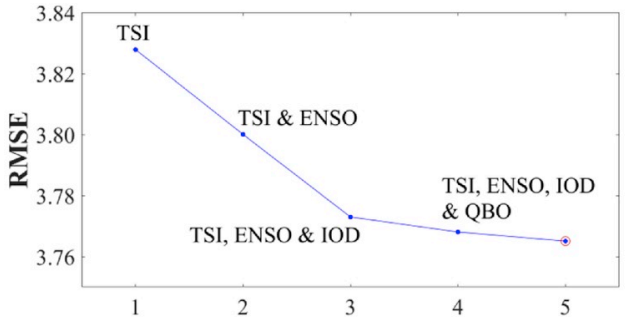

(a)

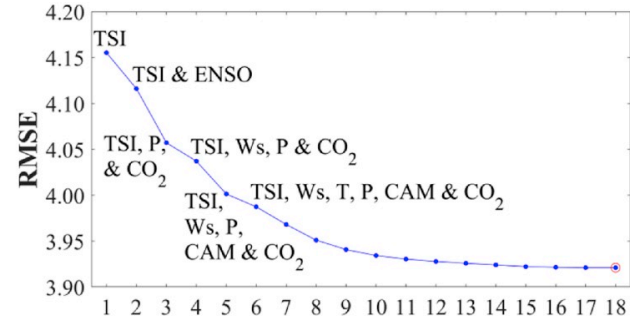

(b)

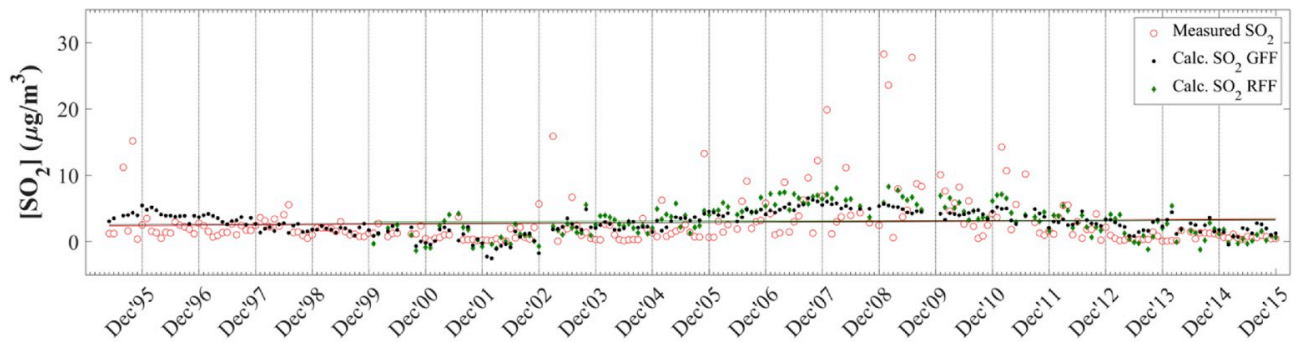

(c)
Fig. 7. RMSE differences between modelled and measured $\mathrm{SO}_{2}$ concentrations as a function of the number of independent variables included in the model for (a) global factors only, and (b) for global, regional and local factors, as well as (c) comparison between measured and modelled $\mathrm{SO}_{2}$ levels for global factor only (black dots), and for global, regional and local factors (green dots). (For interpretation of the references to colour in this figure legend, the reader is referred to the Web version of this article.)

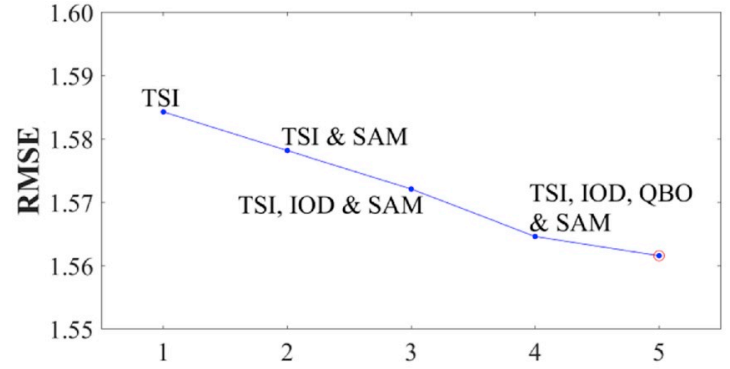

(a)

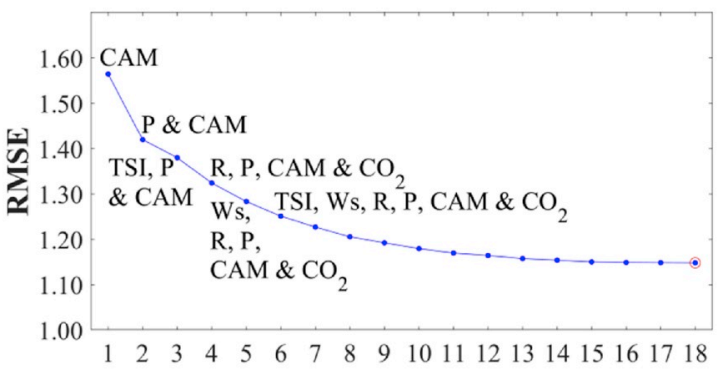

(b)

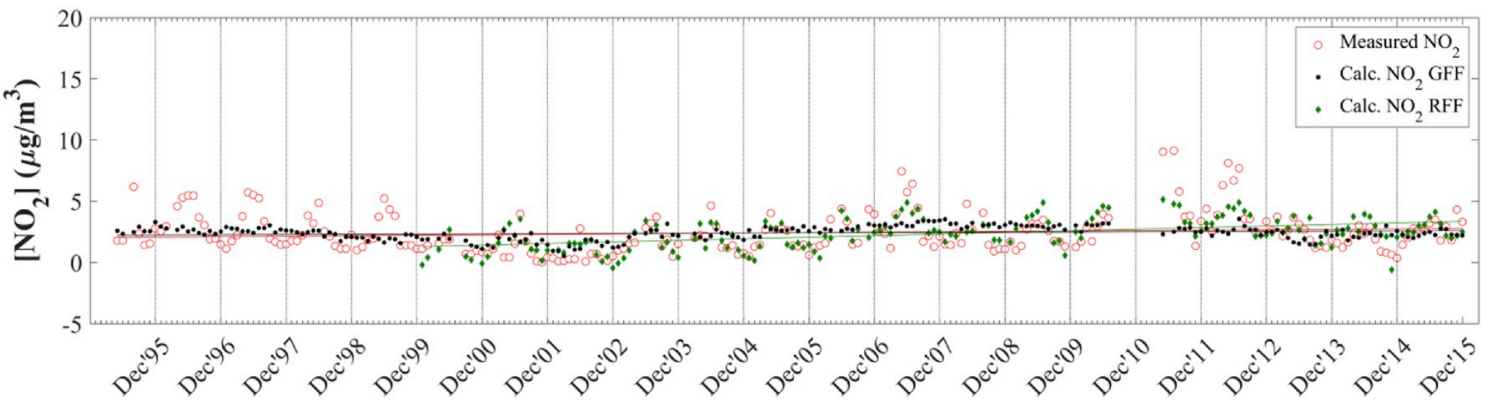

(c)

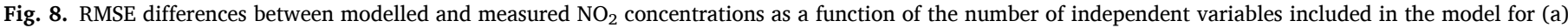

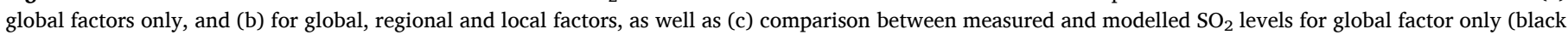

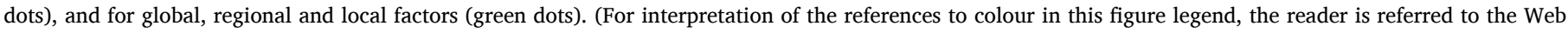
version of this article.)

the influence of the inclusion of local and regional factors in the model on RMSE differences. The RMSE differences are presented as a function of the number of independent variables included in the model with the identities of the most important independent variables also included. The time series of measured concentrations are compared to the modelled values for global factors only, as well as when local and regional factors are included in the model in (c). Also indicated in Figs. 7-9 are linear regression trend lines for measured and modelled
$\mathrm{SO}_{2}, \mathrm{NO}_{2}$ and $\mathrm{O}_{3}$ concentrations. In Table 1 , the coefficients associated with each of the independent variables in the optimum MLR equation (i. e. including all independent variables) in conjunction with their respective RIW\% are presented for the model including only the global force factors, as well as the MLR equation including the global, regional and local factors for $\mathrm{SO}_{2}, \mathrm{NO}_{2}$ and $\mathrm{O}_{3}$. 


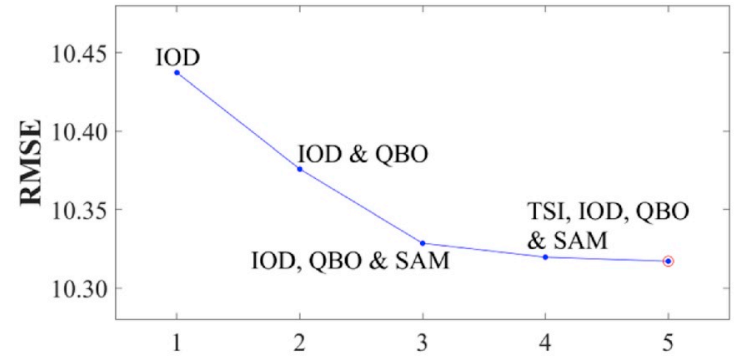

(a)

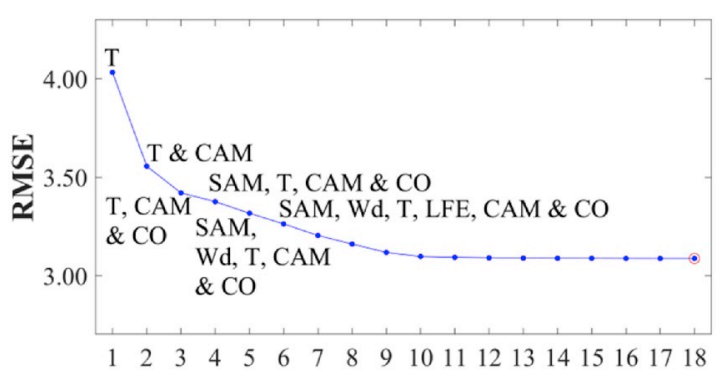

(b)

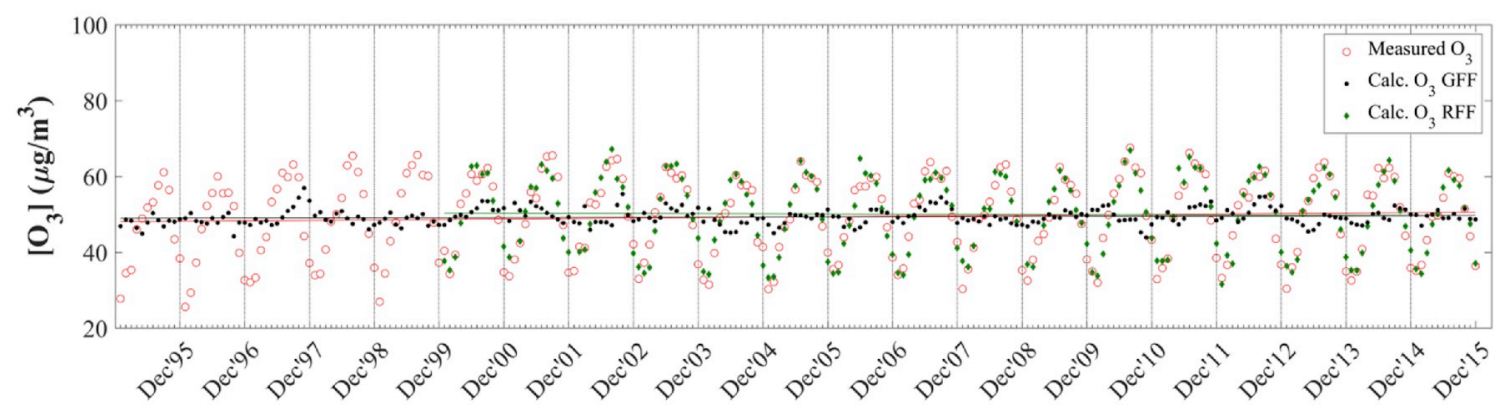

(c)

Fig. 9. RMSE differences between modelled and measured $\mathrm{O}_{3}$ concentrations as a function of the number of independent variables included in the model for (a) global factors only, and (b) for global, regional and local factors, as well as (c) comparison between measured and modelled $\mathrm{SO}_{2}$ levels for global factor only (black dots), and for global, regional and local factors (green dots). (For interpretation of the references to colour in this figure legend, the reader is referred to the Web version of this article.)

\subsubsection{Sulphur dioxide}

It is evident from Fig. 7 that interdependencies between TSI, ENSO and IOD resulted in the largest decrease in RMSE when only global force factors were included for $\mathrm{SO}_{2}$, while the interdependencies between TSI, Ws, T, P, CAM and $\mathrm{CO}_{2}$ made the most significant contribution to decreases in RMSE difference between modelled and measured values when regional and local factors were also included The RIW\% indicates that TSI made a significant contribution, i.e. $81.3 \%$, to the dependent variable when only global force factors were considered, while TSI contributed $60.3 \%$ of the variance when local and regional parameters were also included. In the optimum solution obtained when all factors were included, the RIW\% of ENSO, IOD, T and Ws were 5.3\%, 5.2\%, $4.3 \%$ and $4.2 \%$, respectively. MLR modelling indicates that variances in $\mathrm{SO}_{2}$ concentrations at Cape Point depend mainly on global forcing factors, i.e. global transport patterns of air masses. This is also supported by Ws being the most relevant regional factor, which is indicative of general air mass flow. Therefore the MLR model signifies that $\mathrm{SO}_{2}$ concentrations at CPT GAW are more likely associated with oceanic sources of $\mathrm{SO}_{2}$ (e.g. oxidation of DMS) as previously mentioned (Section 3.2), which are predominantly dependent on global meteorological patterns. The strong negative correlation with TSI could be attributed to greater oxidation capacity of the atmosphere corresponding to higher temperatures resulting in increased oxidation of oceanic $\mathrm{SO}_{2}$. However, this correlation cannot be conclusively explained at this stage and must be further investigated. The influence from local and regional factors on $\mathrm{SO}_{2}$ concentrations is also signified by the influence of T, $\mathrm{P}$ and CAM. As indicated in Section 3.2, $\mathrm{SO}_{2}$ concentrations were slightly higher during June and July in the wet season when CPT GAW is more frequently influenced by air masses passing over the Cape Town conurbation. Therefore the model also reflect the marginal influence of local and regional factors on seasonal variability in $\mathrm{SO}_{2}$ levels at CPT GAW.

Comparison between modelled and measured $\mathrm{SO}_{2}$ concentration time series in Fig. 7, indicates, although relatively weak, slight correlations between modelled and measured $\mathrm{SO}_{2}$ concentrations with an $\mathrm{R}^{2}$ value of 0.165 when only global factors are included in the model. These correlations are marginally improved when local and regional factors are also included in the model, resulting in an $\mathrm{R}^{2}$ value of 0.2371 . Although relatively weak correlations are observed, the modelled $\mathrm{SO}_{2}$ concentration time series mimics the general temporal trend of the measured $\mathrm{SO}_{2}$ time series, with the exception of significantly higher $\mathrm{SO}_{2}$ concentrations. Differences between modelled and measured values can also be attributed to the limitations of passive sampling measurements at CPT GAW, as previously mentioned.

In Fig. 7(c), it is evident that the slope of the 21-year measurement period trend line has a slight positive value reflecting a marginal increase in $\mathrm{SO}_{2}$ concentrations over the 21 -year period, i.e. $0.05 \mu \mathrm{g} \mathrm{m}^{-3}$. $\mathrm{y}^{-1}$. The 21-year dataset also allowed for the calculation of decadal trends, which were determined to be $1.92 \mu \mathrm{g} \mathrm{m}^{-3} \cdot \mathrm{dec}^{-1}$ for the two decades (average $\mathrm{SO}_{2}$ concentrations from 1995 to 2004 were $1.92 \mu \mathrm{g} \mathrm{m}^{-3}$ and average $\mathrm{SO}_{2}$ concentrations from 2005 to 2014 were $3.84 \mu \mathrm{g} \mathrm{m}^{-3}$ ). The annual trends for the two periods identified above as being associated with decreased and increased $\mathrm{SO}_{2}$ concentrations were calculated to be $-0.41 \mu \mathrm{g} \mathrm{m} \mathrm{m}^{-3} \cdot \mathrm{y}^{-1}$ between 1995 and 2002 , and $1.20 \mu \mathrm{g} \mathrm{m}^{-3} \cdot \mathrm{y}^{-1}$ from 2002 to 2009 . Although the 21 -year sampling period is characterised by periods with decreased and increased $\mathrm{SO}_{2}$ levels, it can be deduced that, in general, the observed trend in $\mathrm{SO}_{2}$ concentrations over the 21-year period remained relatively constant. Linear regression trend lines for the modelled $\mathrm{SO}_{2}$ concentrations in Fig. 7(c) correlate with the 21-year trend line obtained for the measured $\mathrm{SO}_{2}$ concentrations. Furthermore, the slope of the trend line for the $\mathrm{SO}_{2}$ levels modelled with global, regional and local factors is exactly the same as the slope of the trend line for the measured $\mathrm{SO}_{2}$ concentrations.

\subsubsection{Nitrogen dioxide}

It is evident from Fig. 8 that the interdependencies between most of the global force factors resulted in the largest decrease in RMSE when only global force factors were included, while RIW\% listed in Table 1 indicates that, similar to modelled $\mathrm{SO}_{2}$ values, TSI also made the most 
significant contribution, i.e. $74.2 \%$ to the variance of the dependent variable (Table 1). IOD made a relatively larger contribution on modelled $\mathrm{NO}_{2}$ values, i.e. $11.9 \%$ compared to its contribution to modelled $\mathrm{SO}_{2}$. When regional and local factors were included in the MLR model, the interdependencies between CAM, R, P, Ws, TSI and $\mathrm{CO}_{2}$ made the most significant contribution to decreases in RMSE difference between modelled and measured values. The RIW\% of CAM, R, P and Ws in the optimum MLR equation obtained when global, regional and local factors are included indicates that these factors explained $12.7 \%, 12.4 \%$, $11.4 \%$ and $11.4 \%$, respectively, of the variance in $\mathrm{NO}_{2}$ levels, while TSI contributed to $7.8 \%$ of the variance. It is evident from the MLR model that regional and local factors play a more important role in $\mathrm{NO}_{2}$ trends at Cape Point. In addition, modelled $\mathrm{NO}_{2}$ concentrations were positively correlated to CAM, indicating higher $\mathrm{NO}_{2}$ concentrations coinciding with increased frequencies of air masses moving over the continent during the wet season, as indicated by the seasonal $\mathrm{NO}_{2}$ pattern (Fig. 4 (b)) and discussed in section 3.2. A positive correlation with population growth also signifies the influence of economic growth and increased energy demand. The decrease in $\mathrm{NO}_{2}$ concentration from 1995 to 2001 is mainly associated with the period during which the new democracy was established in South Africa with companies implementing mitigation technologies in order to comply with international trade requirements (e.g. Westcott et al., 2007). However, it seems that these enhancements in relation to air quality were offset from $2002 / 2003$, which was a period associated with rapid economic and population growth accompanied with a higher energy demand (Vet et al., 2014; Inglesi-Lotz and Blignaut, 2011). In addition, although MLR indicated that global meteorology mainly influenced $\mathrm{SO}_{2}$ variability at CPT GAW, it was also indicated that $\mathrm{P}$ was a local and regional factor that influenced $\mathrm{SO}_{2}$ levels. Therefore, the periods indicate above as being associated with increased and decreased $\mathrm{SO}_{2}$ levels, can also be attributed to the changes in the energy demand. Similarly to $\mathrm{SO}_{2}$, the influence of TSI on $\mathrm{NO}_{2}$ could be ascribed to increased oxidation capacity of the atmosphere. However, as previously mentioned, the influence of TSI on $\mathrm{SO}_{2}$ and $\mathrm{NO}_{2}$ variability cannot be decisively explained at this stage.

It is evident from Fig. 8(c) that, similar to $\mathrm{SO}_{2}$, relatively weak correlations are observed between measured and modelled $\mathrm{NO}_{2}$ concentrations when only global factors are included into the MLR model, with an $\mathrm{R}^{2}$ value of 0.112 , which is lower than the $\mathrm{R}^{2}$ value for $\mathrm{SO}_{2}$. However, the correlation between measured and modelled $\mathrm{NO}_{2}$ levels significantly improves when local and regional factors are included, yielding an $\mathrm{R}^{2}$ value of 0.549 , which can be considered a moderate correlation (Kleynhans et al., 2017). This emphasises the importance of local and regional factors on $\mathrm{NO}_{2}$ concentrations at Cape Point. From Fig. 8(c), it seems that the model, in particular, does not give good estimations for very high $\mathrm{NO}_{2}$ levels. However, in general, the modelled $\mathrm{NO}_{2}$ concentrations correlate relatively well to the observed variability of the measured $\mathrm{NO}_{2}$ concentrations when global, regional and local factors are included.

The slopes of the trend lines for the measured and modelled $\mathrm{NO}_{2}$ concentrations for the 21-year period correlate very well with the annual trend calculated for the measured $\mathrm{NO}_{2}$ levels, i.e. $0.035 \mathrm{\mu g} \mathrm{m}^{-3}$. $\mathrm{y}^{-1}$, indicating a slight inter-annual increase. In addition, the slope of the trend line for the $\mathrm{NO}_{2}$ levels modelled with global, regional and local factors is exactly the same as the slope of the trend line for measured $\mathrm{NO}_{2}$ concentrations (Fig. 8(c)). The calculated decadal trend for the measured dataset was $0.68 \mu \mathrm{g} \mathrm{m}^{-3} \cdot \mathrm{dec}^{-1}$ for the two decades (average $\mathrm{NO}_{2}$ concentrations from 1995 to 2004 were $2.03 \mu \mathrm{g} \mathrm{m}^{-3}$ and average $\mathrm{NO}_{2}$ concentrations from 2005 to 2014 were $2.71 \mu \mathrm{g} \mathrm{m}^{-3}$ ). The annual trends for the two periods identified as being associated with decreased and increased $\mathrm{NO}_{2}$ concentrations were calculated to be $-0.34 \mu \mathrm{g} \mathrm{m}^{-3}$. $\mathrm{y}^{-1}$ from 1995 to 2001 and $0.29 \mu \mathrm{g} \mathrm{m}^{-3} \cdot \mathrm{y}^{-1}$ from 2002 to 2011 . In general, it can also be deduced that the trend in $\mathrm{NO}_{2}$ concentrations over the 21-year measurement period was relatively constant, although characterised by periods of annual decrease and increase in $\mathrm{NO}_{2}$ concentrations.

\subsubsection{Ozone}

Since in-situ measured $\mathrm{O}_{3}$ concentrations were available for CPT $\mathrm{GAW}$, modelled $\mathrm{O}_{3}$ levels were correlated to these measurements, which curtailed the limitations associated with passive sampling of ambient $\mathrm{O}_{3}$. In Fig. 9, the modelled and measured $\mathrm{O}_{3}$ concentrations are related, which indicate weak correlations $\left(\mathrm{R}^{2}\right.$ value of 0.039$)$ between measured and modelled $\mathrm{O}_{3}$ levels when only global force factors are considered (Fig. 9(c)). However, the correlations are significantly improved $\left(\mathrm{R}^{2}\right.$ value of 0.910 ) when regional and local factors are included in the MLR model. This indicates that regional and local factors play a significant role in $\mathrm{O}_{3}$ variability at Cape Point. The very good correlation between modelled and in-situ measured $\mathrm{O}_{3}$ concentrations is also indicative of the limitation associated with passive samplers, especially for a site such as CPT GAW that is influenced by two distinct types of air masses. Comparison of modelled $\mathrm{O}_{3}$ levels to passively derived $\mathrm{O}_{3}$ concentrations yielded $\mathrm{R}^{2}$ values of 0.082 when only global factors were considered, and 0.338 when global, regional and local factors are included in the model. Therefore, although comparison of the $\mathrm{O}_{3}$ concentrations determined with passive samplers with modelled $\mathrm{O}_{3}$ levels also reflect the important influence of local and regional factors on $\mathrm{O}_{3}$ variability, weaker correlation between measured and modelled values are determined.

From the RMSE, plotted as a function of the number of interdependent variables, it is evident that the interdependencies between T, CO, CAM and SAM yield the largest decrease in RMSE when global, regional and local factors are included. The RIW\% of T, CO and CAM were $33.5 \%$, $21.2 \%$ and 10.5 , respectively, which made the most significant contributions in explaining the variances (Table 1). IOD had the largest RIW\% $(43.7 \%)$ when only global factors were included, while it also had the highest, although very low (1.4\%), RIW\% of the global factors when all factors were included in the model. The interdependency between $\mathrm{T}, \mathrm{CO}$ and CAM resulting in the largest decrease in differences between modelled and measured $\mathrm{O}_{3}$ concentrations, as well as their respective highest RIW\% values, signifies the important role of local and regional factors on $\mathrm{O}_{3}$ variability at CPT GAW, as mentioned above. Modelled $\mathrm{O}_{3}$ concentrations are negatively correlated to $\mathrm{T}$, while it is positively correlated to $\mathrm{CO}$ and CAM. Therefore, higher $\mathrm{O}_{3}$ concentrations correspond to lower temperatures, as well as increased frequencies of air masses moving over the continent and higher $\mathrm{CO}$ concentrations during the winter months, as indicated and discussed in section 3.2.

The linear regression trend line of the measured $\mathrm{O}_{3}$ concentrations in Fig. 9 indicates a relatively small positive slope for the 21 -year period, i. e. $0.06 \mu \mathrm{g} \mathrm{m}^{-3} \cdot \mathrm{y}^{-1}$. The decadal trend was calculated to be $0.79 \mu \mathrm{g}$. $\mathrm{m}^{-3} \mathrm{dec}^{-1}$ (average $\mathrm{O}_{3}$ concentration from 1995 to 2004 was $49.0 \mu \mathrm{g} \mathrm{m}^{-3}$ and average $\mathrm{O}_{3}$ concentration from 2005 to 2014 was $49.8 \mathrm{\mu g} \mathrm{m}^{-3}$ ). As observed in Fig. 6, trend analysis also indicates that $\mathrm{O}_{3}$ concentrations remained relative constant during the 21-year sampling period. Furthermore, here, the slope of trend line for modelled $\mathrm{O}_{3}$ values when global, regional and local factors are included, is the same as the slope of trend line of the measured $\mathrm{O}_{3}$ concentrations.

\section{Summary and conclusions}

A 21-year passive sampled dataset for atmospheric $\mathrm{SO}_{2}, \mathrm{NO}_{2}$ and $\mathrm{O}_{3}$ at CPT GAW was explored for their inter-annual and seasonal features. Comparison of $\mathrm{SO}_{2}, \mathrm{NO}_{2}$ and $\mathrm{O}_{3}$ measured at CPT GAW with measurements at other IDAF measurement sites utilising passive samplers indicated that concentrations at CPT GAW were lower than an industrially impacted site, while being generally similar to other African inland ecosystems (with the exception of levels of these gaseous species over forests). $\mathrm{SO}_{2}, \mathrm{NO}_{2}$ and $\mathrm{O}_{3}$ showed seasonal patterns, which were attributed to different factors influencing their levels at CPT GAW. It was indicated that $\mathrm{SO}_{2}$ and $\mathrm{NO}_{2}$ levels are predominantly influenced by the more occurrences of air masses passing over the Cape Town Metropole in the wet winter season and stronger inversions. Increased microbial activity during the wet season can partially explain increased $\mathrm{NO}_{2}$ 
concentrations. The $\mathrm{O}_{3}$ seasonal pattern corresponded to the $\mathrm{NO}_{2}$ seasonality, which can be expected in a $\mathrm{NO}_{\mathrm{x}}$-limited regional background site. Although increased $\mathrm{SO}_{2}$ in January and February coincided with increased biomass burning, the influence of regional biomass burning in the Western Cape was not reflected by $\mathrm{NO}_{2}$ and $\mathrm{O}_{3}$ concentrations.

$\mathrm{SO}_{2}$ and $\mathrm{NO}_{2}$ did indicate inter-annual variability, having periods associated with decreased and increased concentrations. $\mathrm{O}_{3}$, however, did not show any significant inter-annual variability. Seasonal and interannual $\mathrm{SO}_{2}, \mathrm{NO}_{2}$ and $\mathrm{O}_{3}$ variability was further explored with MLR modelling, in which the interdependencies between global, regional and local meteorological factors, as well as population growth, were investigated. Modelling results indicated that variances in $\mathrm{SO}_{2}$ concentrations were predominantly influenced by global force factors, while global, regional and local factors were indicated as playing a significant role in $\mathrm{NO}_{2}$ fluctuations. It was also indicated that variances in $\mathrm{O}_{3}$ concentrations were predominantly associated with regional and local factors. The 21-year trend analysis indicated that $\mathrm{SO}_{2}, \mathrm{NO}_{2}$ and $\mathrm{O}_{3}$ concentrations remained relatively constant.

In this study, the value of a long-term atmospheric measurement dataset is clearly illustrated. This dataset was useful to indicate that $\mathrm{SO}_{2}$, $\mathrm{NO}_{2}$ and $\mathrm{O}_{3}$ concentrations at CPT GAW are influenced by various contributing factors, which resulted in seasonal and inter-annual variability of these inorganic gaseous species. However, future in-situ $\mathrm{NO}_{\mathrm{x}}$ an $\mathrm{SO}_{2}$ analysers at CPT GAW would be most helpful to resolve some of the proposed inferences/deductions, e.g. episodes of anomalous $\mathrm{SO}_{2}$ levels could be linked to emissions from the Saldanha iron smelter. A statistical model could be applied to this long-term dataset, which also signified the most important factors contributing to long-term trends. However, availability of measurements of other factors that could be included in such a model should yield more accurate correlations between modelled and measured values.

\section{Declaration of competing interest}

The authors declare that they have no known competing financial interests or personal relationships that could have appeared to influence the work reported in this paper.

\section{CRediT authorship contribution statement}

J.-S. Swartz: Formal analysis, Methodology, Investigation, Data curation, Writing - original draft. P.G. Van Zyl: Conceptualization, Methodology, Investigation, Writing - review \& editing, Resources, Supervision, Funding acquisition, Project administration. J.P. Beukes: Conceptualization, Methodology, Investigation, Supervision, Resources, Funding acquisition, Project administration. C. Labuschagne: Investigation, Conceptualization. E.-G. Brunke: Investigation, Conceptualization. T. Portafaix: Methodology, Software. C. Galy-Lacaux: Conceptualization, Funding acquisition, Project administration. J.J. Pienaar: Conceptualization, Funding acquisition, Project administration.

\section{Acknowledgements}

The authors would like to acknowledge the International Global Atmospheric Chemistry programme for endorsing the DEBITS programme, as well as Sasol and Eskom for financial support of the South African IDAF project. Assistance with sample deployment and collection by Ms Thumeka Mkololo is also acknowledged. The authors also acknowledge support from the Atmospheric Research in Southern Africa and Indian Ocean (ARSAIO) programme established by the National Center for Scientific Research (CNRS) in France and the National Research Foundation (NRF) in South Africa.

\section{Appendix A. Supplementary data}

Supplementary data to this article can be found online at https://doi.org/10.1016/j.atmosenv.2019.117128.

\section{Appendix}

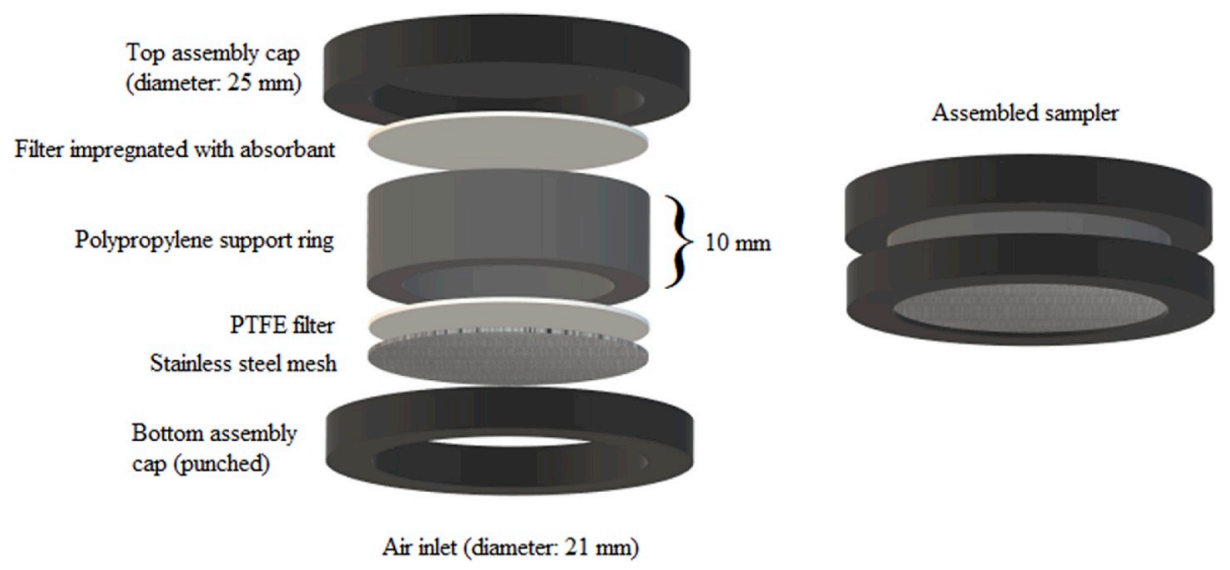

Fig. A1. Design of passive samplers used in this study. 
J.-S. Swartz et al.

Atmospheric Environment $x x x(x x x x) x x x$
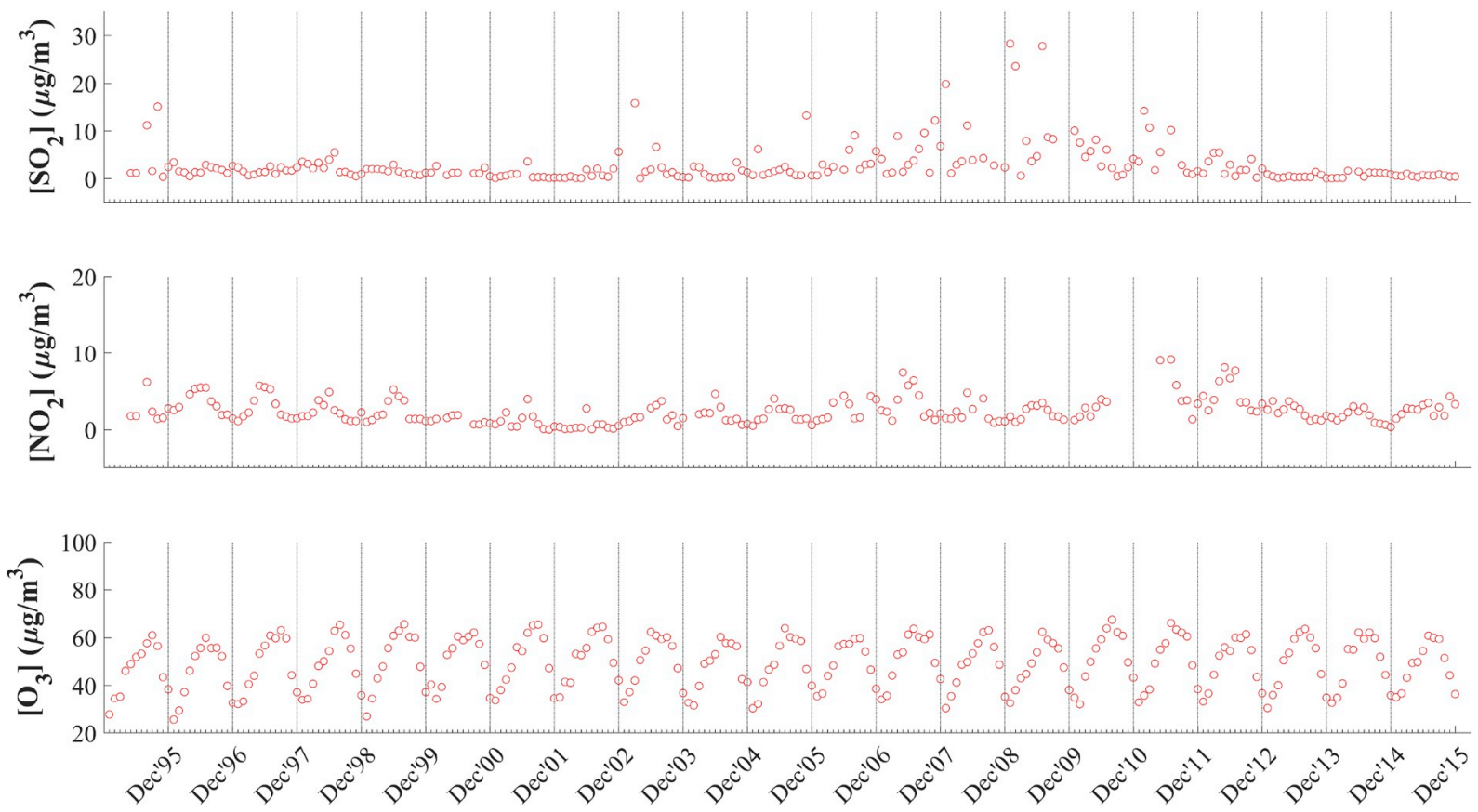

Fig. A2. Time series of monthly average $\mathrm{SO}_{2}, \mathrm{NO}_{2}$ and $\mathrm{O}_{3}$ concentrations measured with passive samplers.

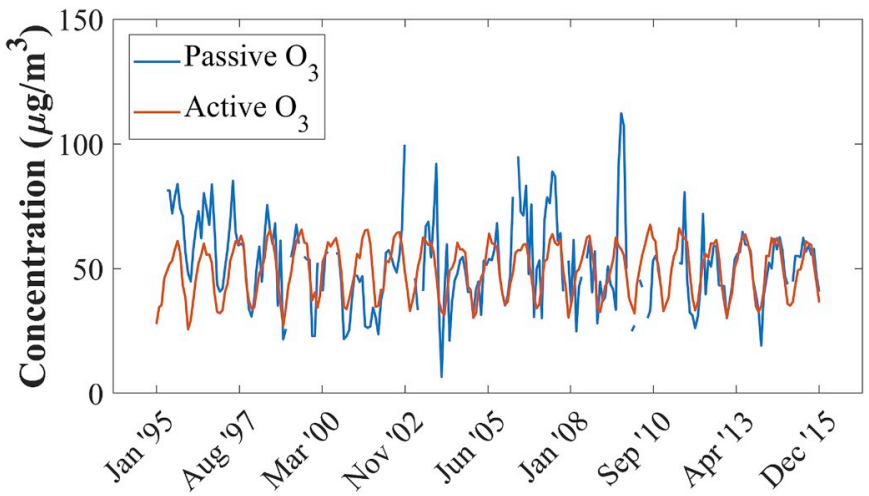

Fig. A3. Time series of $\mathrm{O}_{3}$ concentrations measured with passive samplers and in situ measurements at CPT GAW.

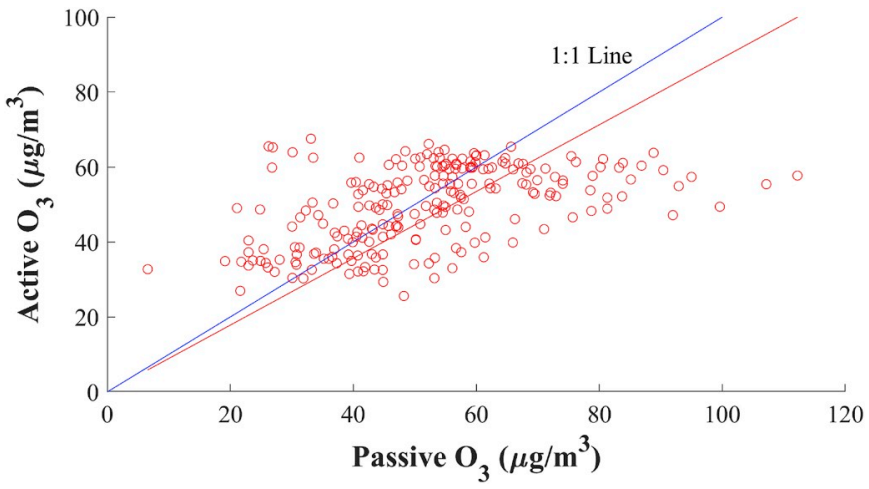

Fig. A4. Correlation between $\mathrm{O}_{3}$ concentrations measured with passive samplers and in situ measurements at CPT GAW.

15 


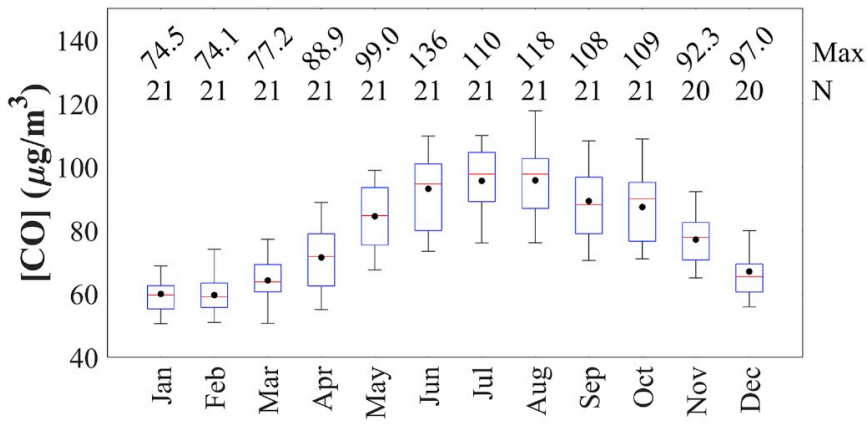

Fig. A5. Monthly averaged in situ measured CO concentrations for the 21-year sampling period at CPT GAW. The red line of each box represents the median, the top and bottom edges of the box the 25th and 75th percentiles, respectively, the whiskers $\pm 2.7 \sigma(99.3 \%$ coverage if the data has a normal distribution $)$ and the black dots the averages. The maximum concentrations and the number of measurements $(\mathrm{N})$ are presented at the top.

\section{References}

Abiodun, B.J., Ojumu, A.M., Jenner, S., Ojumu, T.V., 2014. The transport of atmospheric $\mathrm{NO}_{\mathrm{X}}$ and $\mathrm{HNO}_{3}$ over Cape Town. Atmos. Chem. Phys. 14, 559-575. https://doi.org/ 10.5194/acp-14-559-2014.

ABM, 2016. Indian Ocean influences on Australian climate [Online]. Available: http: //www.bom.gov.au/climate/iod/. (Accessed 26 November 2018). Accessed.

Adon, M., Galy-Lacaux, C., Yoboué, V., Delon, C., Lacaux, J.P., Castera, P., Gardrat, E., Pienaar, J.J., Al Ourabi, H., Laouali, D., Diop, B., Sigha-Nkamdjou, L., Akpo, A., Tathy, J.P., Lavenu, F., Mougin, E., 2010. Long-term measurements of sulfur dioxide, nitrogen dioxide, ammonia, nitric acid and ozone in Africa using passive samplers. Atmos. Chem. Phys. 10, 7467-7487. https://doi.org/10.5194/acp-10-7467-2010.

Baldwin, M.P., Gray, L.J., Dunkerton, T.J., Hammilton, K., Haynes, P.H., Randel, W.J., Holton, J.R., Alexander, M.J., Hirota, I., Horinouchi, T., Jones, D.B.A., Kinnersley, J. S., Marquardt, C., Sato, K., Takahashi, M., 2001. The quasi-biennial oscillation. Rev. Geophys. 39, 179-229. https://doi.org/10.1029/1999RG000073.

Bencherif, H., Diab, R.D., Portafaix, T., Morel, B., Keckhut, P., Moorgawa, A., 2006. Temperature climatology and trend estimates in the UTLS region as observed over a southern subtropical site, Durban, South Africa. Atmos. Chem. Phys. 6, 5121-5128. https://doi.org/10.5194/acp-6-5121-2006.

Botha, R., Labuschagne, C., Williams, A.G., Bosman, G., Brunke, E.G., Rossouw, A., Lindsay, R., 2018. Characterising fifteen years of continuous atmospheric radon activity observations at Cape Point (South Africa). Atmos. Environ. 176, 30-39. https://doi.org/10.1016/j.atmosenv.2017.12.010.

Brunke, E.G., Labuschagne, C., Ebinghaus, R., Kock, H.H., Slemr, F., 2010. Gaseous elemental mercury depletion events observed at Cape Point during 2007-2008. Atmos. Chem. Phys. 10, 1121-1131. https://doi.org/10.5194/acp-10-1121-2010.

Brunke, E.G., Labuschagne, C., Parker, B., Scheel, H.E., Whittlestone, S., 2004. Baseline air mass selection at Cape Point, South Africa: application of ${ }^{222} \mathrm{Rn}$ and other filter criteria to $\mathrm{CO}_{2}$. Atmos. Environ. 38, 5693-5702. https://doi.org/10.1016/j. atmosenv.2004.04.024.

Brunke, E.-G., Labuschagne, C., Scheel, H.E., 2001. Trace gas variations at Cape Point, South Africa, during May 1997 following a regional biomass burning episode. Atmos. Environ. 35 (4), 777-786. https://doi.org/10.1016/S1352-2310(00)00260 0 .

Connell, D.W., 2005. Basic Concepts of Environmental Chemistry. CRC Press.

Conradie, E.H., Van Zyl, P.G., Pienaar, J.J., Beukes, J.P., Galy-Lacaux, C., Venter, A.D., Mkhatshwa, G.V., 2016. The chemical composition and fluxes of atmospheric wet deposition at four sites in South Africa. Atmos. Environ. 146, 113-131. https://doi. org/10.1016/j.atmosenv.2016.07.033.

Dhammapala, R.S., 1996. Use of Diffusive Samplers for the Sampling of Atmospheric Pollutants. MSc, Potchefstroom University for CHE.

Draxler, R.R., Hess, G.D., 2014. Description of the HYSPLIT 4 Modelling System. 7 Ed. Silver Spring. Air Resources Laboratory, Maryland.

Ferm, M., 1991. A Sensitive Diffusional Sampler. IVL Report L91. Swedish Environmenta Research Institute, Göteborg, Sweden.

Fowler, D., Pilegaard, K., Sutton, M.A., Ambus, P., Raivonen, M., Duyzer, J., Simpson, D. Fagerli, H., Fuzzi, S., Schjoerring, J.K., Granier, C., Neftel, A., Isaksen, I.S.A., Laj, P., Maione, M., Monks, P.S., Burkhardt, J., Daemmgen, U., Neirynck, J., Personne, E., Wichink-Kruit, R., Butterbach-Bahl, K., Flechard, C., Tuovinen, J.P., Coyle, M., Gerosa, G., Loubet, B., Altimir, N., Gruenhage, L., Ammann, C., Cieslik, S. Paoletti, E., Mikkelsen, T.N., Ro-Poulsen, H., Cellier, P., Cape, J.N., Horváth, L., Loreto, F., Niinemets, Ü., Palmer, P.I., Rinne, J., Misztal, P., Nemitz, E., Nilsson, D., Pryor, S., Gallagher, M.W., Vesala, T., Skiba, U., Brüggemann, N., ZechmeisterBoltenstern, S., Williams, J., O'dowd, C., Facchini, M.C., De Leeuw, G., Flossman, A., Chaumerliac, N., Erisman, J.W., 2009. Atmospheric composition change: ecosystems-Atmosphere interactions. Atmos. Environ. 43, 5193-5267. https://doi. org/10.1016/j.atmosenv.2009.07.068.

GAWSIS. Global atmosphere Watch station information system [Online]. Available: https://gawsis.meteoswiss.ch/GAWSIS//index.html\#/. (Accessed 23 November 2018). Accessed.

He, J., Bala, R., 2008. Draft report on passive sampler inter-comparison under Malé Declaration. Malé Declaration on Control and Prevention of Air Pollution and its
Likely Transboundary Effect for South Asia. National University of Singapore, Singapore.

Hénault, C., Bizouard, F., Laville, P., Gabrielle, B., Nicoullaud, B., Germon, J.C. Cellier, P., 2005. Predicting in situ soil N2O emission using NOE algorithm and soil database. Glob. Chang. Biol. 11, 115-127. https://doi.org/10.1111/j.13652486.2004.00879.x.

Ho, M., Kiem, A.S., Verdon-Kidd, D.C., 2012. The southern annular mode: a comparison of indices. Hydrol. Earth Syst. Sci. 16, 15. https://doi.org/10.5194/hess-16-967 2012

IDAF, 2011. Network [Online]. Available: http://idaf.sedoo.fr/spip.php?rubrique45. (Accessed 29 June 2017). Accessed.

Inglesi-Lotz, R., Blignaut, J.N., 2011. South Africa's electricity consumption: a sectoral decomposition analysis. Appl. Energy 88 (12), 4779e4784.

IPCC, 2007. Climate change 2007: the physical science basis. In: Solomon, S., Qin, D., Manning, M., Chen, Z., Marquis, M., Averyt, K.B., Tignor, M., Miller, H.L. (Eds.), Contribution of Working Group I to the Fourth Assessment Report of the Intergovernmental Panel on Climate Change (Cambridge, United Kingdom and New York, NY, USA).

Jaars, K., Beukes, J.P., Van Zyl, P.G., Venter, A.D., Josipovic, M., Pienaar, J.J., Vakkari, V., Aaltonen, H., Laakso, H., Kulmala, M., Tiitta, P., Guenther, A., Hellén, H., Laakso, L., Hakola, H., 2014. Ambient aromatic hydrocarbon measurements at Welgegund, South Africa. Atmos. Chem. Phys. Discuss. 14 7075-7089. https://doi.org/10.5194/acp-14-7075-2014.

Kaufman, Y.J., Ichoku, C., Giglio, L., Korontzi, S., Chu, D.A., Hao, W.M., Li, R.R., Justice, C.O., 2003. Fire and smoke observed from the Earth Observing System MODIS instrument: products, validation, and operational use. Int. J. Remote Sens. 24, 1765-1781. https://doi.org/10.1080/01431160210144741.

Kleynhans, E., Beukes, J.P., Van Zyl, P.G., Bunt, J., Nkosi, N., Venter, M., 2017. The effect of carbonaceous reductant selection on chromite pre-reduction. Metall. Mater. Trans. B 48, 827-840. https://doi.org/10.1007/s11663-016-0878-4.

KMNI, 2016. Monthly DMI HadISST1 [Online]. Available: http://climexp.knmi.nl/get indices. cgi? WMO $=$ UKMOData/hadisst1 dmi\&STATION=DMI Had

SST1\&TYPE=i\&id=someone@somewhere. (Accessed 22 December 2016). Accessed.

KMNI, 2016. Monthly measured total solar irradiance [Online]. Available: http://climex p.knmi.nl/getindices.cgi?WMO=PMODData/tsi\&STATION=measured total solar i rradiance\&TYPE=i\&id=someone@somewhere. (Accessed 22 December 2016). Accessed.

Korhonen, K., Giannakaki, E., Mielonen, T., Pfüller, A., Laakso, L., Vakkari, V., Baars, H., Engelmann, R., Beukes, J.P., Van Zyl, P.G., Ramandh, A., Ntsangwane, L., Josipovic, M., Tiitta, P., Fourie, G., Ngwana, I., Chiloane, K., Komppula, M., 2014. Atmospheric boundary layer top height in South Africa: measurements with lidar and radiosonde compared to three atmospheric models. Atmos. Chem. Phys. 14, 4263-4278. https://doi.org/10.5194/acp-14-4263-2014.

Kraha, A., Turner, H., Nimon, K., Reichwein Zientek, L., Henson, R.K., 2012. Tools to support interpreting multiple regression in the face of multicollinearity. Front. Psychol. 3, 1-16. https://doi.org/10.3389/fpsyg.2012.00044.

Laban, T.L., Van Zyl, P.G., Beukes, J.P., Vakkari, V., Jaars, K., Borduas-Dedekind, N., Josipovic, M., Thompson, A.M., Kulmala, M., Laakso, L., 2018. Seasonal influences on surface ozone variability in continental South Africa and implications for air quality. Atmos. Chem. Phys. 15491-15514. https://doi.org/10.5194/acp-18-154912018 .

Labuschagne, C., Kuyper, B., Brunke, E.-G., Mokolo, T., Van Der Spuy, D., Martin, L., Mbambalala, E., Parker, B., Khan, M.a.H., Davies-Coleman, M.T., Shallcross, D.E., Joubert, W., 2018. A review of four decades of atmospheric trace gas measurements at Cape Point, South Africa. Trans. R. Soc. S. Afr. 73, 113-132. https://doi.org/ 10.1080/0035919X.2018.1477854.

Lacaux, J.P., Tathy, J.P., Sigha, L., 2003. In: Acid Wet Deposition in the Tropics: Two Case Studies Using DEBITS Measurements. IGACtivities Newsletter of the International Global Atmospheric Chemistry Project.

Lorenzo-Seva, U., Ferrando, P.J., Chico, E., 2010. Two SPSS programs for interpreting multiple regression results. Behav. Res. Methods 42, 29-35. https://doi.org/ 10.3758/BRM.42.1.29. 
Lourens, A.S., Beukes, J.P., Van Zyl, P.G., Fourie, G.D., Burger, J.W., Pienaar, J.J., Read, C.E., Jordaan, J.H., 2011. Spatial and temporal assessment of gaseous pollutants in the Highveld of South Africa. South Afr. J. Sci. 107, 1-8. https://doi. org/10.4102/sajs.v107i1/2.269.

Ludwig, J., Meixner, F.X., Vogel, B., Förstner, J., 2001. Soil-air exchange of nitric oxide: an overview of processes, environmental factors, and modeling studies. Biogeochemistry 52, 225-257. https://doi.org/10.1023/A:1006424330555.

Marshall, G., 2018. An observation-based southern Hemisphere annular mode index [Online]. United Kingdom. Available: http://www.nerc-bas.ac.uk/icd/gjma/sam. html. (Accessed 28 August 2018). Accessed.

Martins, J.J., Dhammapala, R.S., Lachmann, G., Galy-Lacaux, C., Pienaar, J.J., 2007. Long-term measurements of sulphur dioxide, nitrogen dioxide, ammonia, nitric acid and ozone in southern Africa using passive samplers. South Afr. J. Sci. 103, 336-342.

Monks, P., Leigh, R., 2009. Tropospheric chemistry and air pollution. In: Hewitt, C.N., Jackson, A.V. (Eds.), Atmospheric Science for Environmental Scientists. WileyBlackwell, United Kingdom.

Nathans, L.L., Oswald, F.L., Nimon, K., 2012. Interpreting multiple linear regression: a guidebook of variable importance. Pract. Assess. Res. Eval. 17, 1-19.

NOAA, 2015. Climate indices: monthly atmospheric and ocean time series [Online]. Available: https://www.esrl.noaa.gov/psd/data/climateindices/list/. (Accessed 22 December 2016). Accessed.

NOAA, 2015. Monthly atmospheric and SST indices [Online]. Available: http://www.cp c.ncep.noaa.gov/data/indices/. (Accessed 22 December 2016). Accessed.

NRC, 1991. Rethinking the Ozone Problem in Urban and Regional Air Pollution. The National Academies Press, Washington, DC.

Ojumu, A.M., 2013. Transport of Nitrogen Oxides and Nitric Acid Pollutants over South Africa and Air Pollution in Cape Town. MSc, University of South Africa.

Oltmans, S.J., Lefohn, A.S., Shadwick, D., Harris, J.M., Scheel, H.E., Galbally, I., Tarasick, D.W., Johnson, B.J., Brunke, E.G., Claude, H., Zeng, G., Nichol, S., Schmidlin, F., Davies, J., Cuevas, E., Redondas, A., Naoe, H., Nakano, T., Kawasato, T., 2013. Recent tropospheric ozone changes: a pattern dominated by slow or no growth. Atmos. Environ. 67, 331-351. https://doi.org/10.1016/j. atmosenv.2012.10.057.

Roy, D.P., Boschetti, L., Justice, C.O., Ju, J., 2008. The collection 5 MODIS burned area product: global evaluation by comparison with the MODIS active fire product. Remote Sens. Environ. 112, 3690-3707. https://doi.org/10.1016/j.rse.2008.05.013.

Saji, N.H., Yamagata, T., 2003. Possible impacts of Indian Ocean Dipole mode events on global climate. Clim. Res. 25, 151-169. https://doi.org/10.3354/cr025151.

Seinfeld, J.H., Pandis, S.N., 2006. Atmospheric Chemistry and Physics: from Air Pollution to Climate Change. Wiley.

Slemr, F., Brunke, E.G., Whittlestone, S., Zahorowski, W., Ebinghaus, R., Kock, H.H., Labuschagne, C., 2013. 222Rn-calibrated mercury fluxes from terrestrial surface of southern Africa. Atmos. Chem. Phys. 13, 6421-6428. https://doi.org/10.5194/acp13-6421-2013.

Stenseth, N.C., Ottersen, G., Hurrell, J.W., Mysterud, A., Lima, M., Chan, K., Yoccoz, N. G., Ådlandsvik, B., 2003. Review article. Studying climate effects on ecology through the use of climate indices: the north Atlantic oscillation, El Niño southern oscillation and beyond. Proc. R. Soc. Lond. B 270, 2087-2096. https://doi.org/10.1098/ rspd.2003.2415.
Stewart, D.J., Taylor, C.M., Reeves, C.E., Mcquaid, J.B., 2008. Biogenic nitrogen oxide emissions from soils: impact on $\mathrm{NO}_{\mathrm{x}}$ and ozone over west Africa during AMMA (African Monsoon Multidisciplinary Analysis): observational study. Atmos. Chem. Phys. 8, 2285-2297. https://doi.org/10.5194/acp-8-2285-2008.

Swap, R.J., Annegarn, H.J., Suttles, J.T., King, M.D., Platnick, S., Privette, J.L., Scholes, R.J., 2003. Africa burning: a thematic analysis of the southern African regional science initiative (SAFARI 2000). J. Geophys. Res. 108 (D13), 8465. https://doi.org/10.1029/2003JD003747.

Tiitta, P., Vakkari, V., Croteau, P., Beukes, J.P., Zyl, P.G.V., Josipovic, M., Venter, A.D., Jaars, K., Pienaar, J.J., Ng, N.L., Canagaratna, M.R., Jayne, J.T., Kerminen, V.M., Kokkola, H., Kulmala, M., Laaksonen, A., Worsnop, D.R., Laakso, L., 2014. Chemical composition, main sources and temporal variability of $\mathrm{PM}_{1}$ aerosols in southern African grassland. Atmos. Chem. Phys. 14, 1909-1927. https://doi.org/10.5194/ acp-14-1909-2014.

Toihir, A.M., Portafaix, T., Sivakumar, V., Bencherif, H., Pazmiño, A., Bègue, N., 2018. Variability and trend in ozone over the southern tropics and subtropics. Ann. Geophys. 36, 381-404. https://doi.org/10.5194/angeo-36-381-2018.

UNESCO, 2015. Cape floral region protected areas [Online]. Available: http://whc.unesc o.org/en/list/1007/. (Accessed 20 June 2017). Accessed.

Vakkari, V., Beukes, J.P., Laakso, H., Mabaso, D., Pienaar, J.J., Kulmala, M., Laakso, L., 2013. Long-term observations of aerosol size distributions in semi-clean and polluted savannah in South Africa. Atmos. Chem. Phys. 13, 1751-1770. https://doi.org/ 10.5194/acp-13-1751-2013.

Van Zyl, P.G., Beukes, J.P., Du Toit, G., Mabaso, D., Hendriks, J., Vakkari, V., Tiitta, P., Pienaar, J.J., Kulmala, M., Laakso, L., 2014. Assessment of atmospheric trace metals in the western Bushveld Igneous Complex, South Africa. South Afr. J. Sci. 110, 1-11. https://doi.org/10.1590/sajs.2014/20130280.

Venter, A.D., Jaars, K., Booyens, W., Beukes, J.P., Van Zyl, P.G., Josipovic, M., Hendriks, J., Vakkari, V., Hellen, H., Hakola, H., Aaltonen, H., Ruiz-Jimenez, J., Riekkola, M.L., Laakso, L., 2015. Plume characterization of a typical South African braai: research article. S. Afr. J. Chem. 68, 181-194. https://doi.org/10.17159/ 0379-4350/2015/v68a25.

Venter, A.D., Vakkari, V., Beukes, J.P., Van Zyl, P.G., Laakso, H., Mabaso, D., Tiitta, P., Josipovic, M., Kuimala, M., Pienaar, J.J., Laakso, L., 2012. An air quality assessment in the industrialized western Bushveld Igneous Complex, South Africa. South Afr. J. Sci. 108, 10. https://doi.org/10.4102/sajs.V108i9/10.1059.

Vet, R., Artx, R.S., Carou, S., Shaw, M., Ro, C., Aas, W., Baker, A., Bowersox, V.C., Dentener, F., Galy-Lacaux, C., Hou, A., Pienaar, J.J., Gillet, R., Forti, M.C., Gromov, S., Hara, H., Khodzher, T., Mahowald, N.M., Nickovic, S., Rao, P.S.P., Reid, N.W., 2014. A global assessment of precipitation chemistry and deposition of sulfur, nitrogen, sea salt, base cations, organic acids, acidity and $\mathrm{pH}$, and phosphorus. Atmos. Environ. 93, 3-100.

Westcott, G., Tacke, M., Schoeman, N., Morgan, N., 2007. Impala Platinum Smelter, Rustenburg: an integrated smelter off-gas treatment solution. J. S. Afr. Inst. Min. Metall 107, 281-287.

Wicking-Baird, M.C., De Villiers, M.G., Dutkiewicz, R., 1997. The Cape Town Brown Haze Study. 